\title{
KOMPLEKSINIO POŽIŪRIO İ PACIENTŲ SAUGĄ IR RIZIKOS VALDYMĄ SVEIKATOS PRIEŽIŪROS ORGANIZACIJOSE PAIEŠKA
}

\author{
Laimutis Paškevičius \\ Mykolo Romerio universiteto \\ Politikos ir vadybos fakulteto Politikos mokslų institutas \\ Valakupių g. 5, LT-10101 Vilnius, Lietuva \\ Telefonas (+370 6) 9849757 \\ Elektroninis paštas laimutis.paskevicius@medcentras.lt \\ Pateikta 2014 m. vasario 12 d., parengta spausdinti 2014 m. kovo 17 d.
}

doi:10.13165/SPV-14-1-6-10

\section{Santrauka}

Pacientai turi teise i saugia ir kokybiška sveikatos priežiūrą. Tačiau moksliniai tyrimai pacientų saugos srityje rodo, kad nepageidaujami ịvykiai, dèl jų ịvykę sveikatos pažeidimai ir mirtys sveikatos priežiūros sistemoje yra dažni ir sukelia ženklius moralinius, socialinius bei finansinius nuostolius. Globalūs pokyčiai paskatino sveikatos priežiūros sektorių, jo organizacijas daugiau dèmesio skirti sveikatos priežiūros paslaugu saugai ir kokybei, diegti pacientu saugos ir rizikos valdymo sistemas. Tačiau, trūkstant kompleksinio ir sisteminio požiūrio $\mathfrak{i}$ pacientų sauga ir rizikos valdymą, nacionaliniu (šalies) ar lokaliu (asmens sveikatos priežiūros įstaigos) lygiu taikomos pacientu saugos priemonés dažnai stokoja efektyvumo. Šiuo tikslu straipsnyje išanalizuotas ir atskleistas kompleksinis požiūris į pacientu sauga ir rizikos valdyma, jo svarba planuojant bei diegiant pacientu saugos ir rizikos valdymo sistemas ar priemones sveikatos priežiüros organizacijose.

Reikšminiai žodžiai: pacientu sauga, rizikos valdymas, nepageidaujamas ǐvykis, kompleksinis požiūris, sociotechninè sistema.

\section{Ivadas}

Aktualumas. Pacientai turi teisę ị saugią ir kokybišką sveikatos priežiūrą (SP), tačiau moksliniai tyrimai pacientų saugos (PS) srityje atskleide, kad nepageidaujami ịvykiai (Nİ), jų sukeliami sveikatos pažeidimai ir mirtys sveikatos priežiūros sistemoje (SPS) yra dažni ir sukelia ženklius moralinius, socialinius bei finansinius nuostolius. Todèl pacientų saugos užtikrinimas daugelyje valstybių tapo prioritetu planuojant, organizuojant ar pertvarkant sveikatos priežiūrą nacionaliniu (šalies) ar lokaliu (asmens sveikatos priežiūros įstaigos (ASPI) lygiu.

Išskirtini šie pagrindiniai veiksniai, paskatinę uždaro SP sektoriaus postūmị atvirumo, nuolatinio kokybės gerinimo ir PS užtikrinimo link. Pirma, dèl visuomenès demografinių 
pokyčių, ilgejjančios vidutinės gyvenimo trukmès, augančių pacientų sveikatos priežiūros poreikių ir lūkesčių, sukèlusių sunkiai valdomą SP išlaidų augimą. Antra, dèl sparčios medicinos mokslo ir praktikos pažangos, SP technologijų inovacijų bei plètros, teisinės bazės kaitos, didèjančio SP specialistų trūkumo, nuolat vykstančių SP sektoriaus reformų sukeliama didelè įtampa SP sektoriuje, daranti sveikatos priežiūrą vis sudètingesnę ir rizikingesnę tiek pacientams, tiek SP darbuotojams. Trečia, dèl visuomenès, žiniasklaidos, politikų ir sveikatos priežiūros vadybininkų demesị patraukusių mokslinių tyrimų PS srityje rezultatų, atskleidusių ženklius SP sektoriaus organizacijų vadybos ir veiklos kokybès trūkumus, lemiančius žemą efektyvumą, didelị Nı̨ skaičių bei jų sukeliamus ženklius nuostolius. Ir ketvirta, dèl globalizacijos procesų, apėmusių sveikatos priežiūros paslaugų (SPP) rinką, kai pacientai, ieškodami prieinamesnių, saugesnių, modernesnių bei palankesnès kainos SPP, vyksta jų i kitas valstybes. Sparčiai besivystantis sveikatos (medicinos) turizmas kelia naujus saugos ir kokybės reikalavimus šalių nacionalinèms SP sistemoms.

Reaguodamos ị šiuos esminius aplinkos iššūkius SP sektoriaus organizacijos, siekdamos užtikrinti pacientams teikiamų SPP saugą ir kokybę, perimdamos kitų ūkio šakų rizikos valdymo patirtị, pradejjo diegti pacientų saugos ir rizikos valdymo (PSRV) sistemas, tačiau ne visuomet ịvertindamos ir atsižvelgdamos ị SP sektoriaus ir jo organizacijų kompleksiškumo svarbą. Sistemų tyrëjai SP sektorių ir jo organizacijas priskiria kompleksinems (sudètinèms) atviroms dinaminèms prisitaikančioms sociotechninėms sistemoms, sudarytoms iš daugybès įvairių, tarpusavyje glaudžiais ryšiais susijusių elementų (žmonių, technikos, procesų, informacijos, kt.), veikiančių nuolat kintančioje aplinkoje, siekiant bendrų tikslų. Paveikus atskirą šios sistemos komponentą, per įvairiapusius tarpusavio ryšius veikiami kiti sistemos elementai bei jų aplinka (kontekstas), todèl sukeliami nuspejjami (prognozuoti) bei nenuspejjami (neprognozuoti) sistemos elgsenos pokyčiai ir rezultatai (pageidaujami bei nepageidaujami). Fragmentinis PSRV dèmesị sutelkiant ị atskirų „brokuotų“ sistemos komponentų taisymus ar šalinimus, neįvertinus tokių intervencijų visuminio poveikio sistemai, dažnai sukelia naujas rizikas bei nepageidaujamas pasekmes. Stokojant kompleksinio sisteminio požiūrio ị PS bei PSRV, SP sektoriuje, nacionaliniu (šalies) ar lokaliu (ASPİ) lygiu igyvendinamos PS intervencijos pasižymi mažu efektyvumu, neatneša planuotų rezultatų.

Šio straipsnio tikslas - apžvelgus tradicinio ir modernaus požiūrių i pacientų saugą teorinius aspektus, pasiūlyti kompleksinị sisteminị mokslinị požiūrị ị PSRV, suteiksiantị galimybę SP specialistams ir vadybininkams geriau suprasti PSRV kompleksiškumo sudètinèse dinaminėse atvirose sociotechninėse SP organizacijose svarbą, diegiant bei tobulinant PSRV sistemas, modelius, technikas ar priemones SP organizacijose.

Metodai: šiame darbe taikyti mokslinès literatūros, interaktyvių šaltinių analizès, palyginamosios analizès, apibendrinimo, modeliavimo metodai.

\section{Pacientų saugos problematika sveikatos priežiūroje}

I saugos problemas sveikatos priežiūroje visuomenè dẻmesị atkreipe dar devynioliktojo šimtmečio antroje pusèje, kai $1863 \mathrm{~m}$. slaugytoja F. Nightingale savo „Užrašuose apie ligonines“ pažymejjo, kad „būtina ligoninése ịtvirtinti pirmaeilị reikalavimą - nepakenkti sergantiesiems“, nes „mirtingumas ligoninėse, ypač dideliuose ir tankiai apgyvendintuose miestuose, yra ženkliai didesnis negu pacientų, sergančių tomis pačiomis ligomis ir gydomų ne ligoninėse, mirtingumas ${ }^{\text {"1. }}$. JAV Harvardo universiteto $1991 \mathrm{~m}$. atlikta Medicinos praktikos studija

Sharpe, V. A.; Faden, A. I. Medical Harm. Historical, Conceptual and Ethical Dimensions of Iatrogenic Illness. Cambridge University Press. Cambridge, 1998. 
parodè, kad 3,7 \% hospitalizacijos atvejų įvyko NI, iš jų tik 27,6 \% buvo dèl praktikos klaidų, o $58 \%$ - dèl kitų su sveikatos priežiūra susijusių ịvykių, kurių buvo galima išvengti² $1992 \mathrm{~m}$. JAV Jutos ir Kolorado valstijose atlikta studija parodè, kad NI buvo nustatyti 2,9 \% hospitalizacijos atvejų, iš kurių 6,6\% (0,13\% visų hospitalizacijos atvejų) baigèsi mirtimi ${ }^{3}$. Net $53 \%$ NI buvo įvardinti kaip išvengiami. JAV Medicinos instituto atlikti tyrimai atskleidè, kad JAV nuo 44 tūkst. iki 98 tūkst. pacientų miršta kasmet ligoninėse nuo mirčių, kurių buvo galima išvengti ${ }^{4}$. JAV „Health Grades“ kompanijos 2005 m. atlikta studija ${ }^{5}$ nustate, kad 2001-2003 m. laikotarpiu îvyko per 1,18 mln. NIt, kasmet apie 195 tūkst. pacientų JAV mirè nuo potencialiai išvengiamų klaidų medicinoje, o ši problema buvo įvardinta nacionalinio masto epidemija. 2010 m. JAV paskelbtas tyrimas atskleidè, kad 13,5 \% pagal Medicare programą hospitalizuotų pacientų NI patyrè ligoninèse, dèl to prailgèjo hospitalizacijos laikotarpis, prireikè intervencijų gyvybei palaikyti, pacientams buvo sukelta nuolatinė negalia ar ịvyko mirtis. Australijoje 1995 m. atlikta Sveikatos priežiūros kokybès studija, kurioje buvo panaudota Harvardo Medicinos praktikos studijos metodologija, nustate, kad NI sudare 16,6 \% hospitalizacijos atvejų (patikslinus šios studijos rezultatus pagal patikslintą metodiką - $13 \%$ hospitalizacijos atvejų) ir tai kasmet sukelia apie 36 tūkst. ilgalaikio invalidumo atvejų bei 10-14 tūkst. pacientų mirčių nuo NI, kurių būtų buvę galima išvengti ${ }^{6}$. Apskaičiuota, kad Jungtinèje Karalystejje NIt, sukeliantys žalą pacientams, įvyksta apie $10 \%$ visų hospitalizacijos atvejų (tai sudaro apie 850 tūkst. NI per metus) ${ }^{7}$. Panašus Nİ dažnis (apie $10 \%$ hospitalizacijos atvejų) nustatytas atlikus mokslines studijas Naujoje Zelandijoje ${ }^{8}$ ir Kanadoje ${ }^{9}$. Nustatyta, kad apie 10 \% Europos ligoninėse $2000 \mathrm{~m}$. besigydžiusių pacientų patyrẻ NI̦, kurių daugumos buvo galima išvengti ${ }^{10}$.

Apibendrinus Europos šalyse atliktų mokslinių tyrimų duomenis, nustatyta, kad NI patiria 8-12 \% ligoninėse gydomų pacientų. ES valstybėse nuo su SP susijusių infekcijų nukenčia apie $5 \%$ hospitalizuotų pacientų, tai sudaro apie $4,1 \mathrm{mln}$. pacientų per metus, o dèl šių infekcijų kasmet miršta per 37 tūkst. žmonių ${ }^{11}$.

2 Governments and patient safety in Australia, the United Kingdom and the United States. A review of policies, institutional and funding frameworks, and current initiatives. Report prepared for the Advisory Committee on Health Services by Working group on Quality of Health Care Services. 2002.

3 Thomas, E. J., et al. Incidence and types of adverse events and negligent care in Utah and Colorado. Med Care. 2000, 38: 261-271.

4 Institute of Medicine. Committee on Quality of Health Care in America. To Err is Human: Building a Safer Health System. Washington, DC: National academy Press [interaktyvus]. 2000 [žiūrèta 2013-12-28]. <https:// download.nap.edu/login.php?record_id=9728\&page=\%2Fdownload.php\%3Frecord_id\%3D9728>.

5 Health Grades Quality study. Second Annual. Patient Safety in American Hospital Report [interaktyvus]. 2005 [žiūrèta 2013-12-11]. <http://hg-article-center.s3-website-us-east-1.amazonaws. com/a6/43/b94f277e492d9a416af1d51b487d/PatientSafetyInAmericanHospitalsReport2005.pdf>.

6 Patient safety: towards sustainable improvement, Fourth report to the Australian Health Ministers' Conference. Australian council for safety and quality in health care. Commonwealth of Australia 2003.

7 An organization with a memory. Report of an Expert Group on Learning from Adverse Events in the NHS Chaired by the Chief Medical Officer. London.The Stationary Office, 2000: vii-viii; 5.

8 Davis, P., et al. Adverse events in New Zealand public hospitals: occurrence and impact. New Zealand Medical Journal. 2002, 115 (1167): U271.

9 Baker, G. R.; Norton, P. G.; Flintolf, V., et al. The Canadian Adverse events Study: the incidence of adverse events among hospital patients in Canada. Canadian Medical Association Journal. 2004, 179(11): 1678-1686.

10 Standing Committee of the Hospitals of the EU. The quality of health care/hospital activities: Report by the Working Party on quality care in hospitals of the subcommittee on coordination. 2000.

11 ES Tarybos $2009 \mathrm{~m}$. birželio 9 d. Rekomendacija dèl pacientų saugos ir su sveikatos priežiūra susijusių infekcijų prevencijos ir kontrolès 2009/C 151/01 [interaktyvus]. 2009 [žiūrèta 2013-12-09]. <http:// ec.europa.eu/health/patient_safety/docs/council_2009_lt.pdf $>$. 
NI sukelia valstybėms, jų SP sektoriams ženklius finansinius nuostolius. JAV kasmet NI padaryta žala vertinama nuo $17 \mathrm{mlrd}$. USD iki $29 \mathrm{mlrd}$. USD. Vien gydymo vaistais klaidos kasmet JAV ligoninèms atneša per 2 mlrd. USD nuostolių. Jungtinejje Karalystėje dèl įvykusių NI hospitalizacijos laikotarpio prailgejjimas šalies sveikatos sistemai papildomai kainuoja apie 2 mlrd. GBP, teisminiams ieškiniams patenkinti kasmet papildomai išleidžiama dar apie $400 \mathrm{mln}$. GBP, o per daugelị metų susikaupusi potencialių ieškinių suma gali siekti per 2,4 mlrd. GBP. Jungtinèje karalystejje SP sistema dèl hospitalinių infekcijų (iš kurių apie $15 \%$ yra išvengiamos) kasmet praranda apie 1 mlrd. GBP ${ }^{12}$. Kanados pacientų saugos instituto duomenimis, per 2009-2010 m. laikotarpi aktyvaus stacionarinio gydymo paslaugas teikiančiose ASPI ívykusių NI ekonominè našta Kanados sveikatos sistemai sudarè apie $1,1 \mathrm{mlrd}$. JAV dolerių, iš jų išvengiamų NI - apie $397 \mathrm{mln}$. JAV dolerių. Vienam NI priskirtini kaštai svyravo nuo 2162 JAV dolerių iki 11846 JAV dolerių. Australijoje 1992 m. atliktais tyrimais nustatyta, kad dèl NI prailgejusio pacientų gydymosi ligoninèse laiko kasmet papildomai išleidžiama per $867 \mathrm{mln}$. USD.

Lietuvoje nèra atliktų išsamių NĮ pasireiškimo dažnio ir jų sukeliamų pasekmių tyrimų. D. Brogienè savo disertacijoje vertino SPP kokybę pacientų požiūriu analizuodama pacientų teisių funkcionavimą praktikoje. Higienos instituto $2008 \mathrm{~m}$. atliktas tyrimas ${ }^{13}$, kuriuo buvo siekiama atskleisti medikų ir pacientų požiūrị i $\mathrm{NI}$ ir jų priežastis, parodè, kad kas dešimtas medikas nežinojo, kas yra Nİ, 4,5 \% medikų pripažino, kad jų asmeninèje praktikoje NI ịvyksta dažnai (keletą kartų per mėnesį); daugiau kaip $80 \%$ medikų pažyméjo, kad NI analizuojami jų ASPIt, dažniausiai aptariant juos skyriuje. Ernst \& Young audito kompanijos 2013 m. atliktoje studijoje „Analizė apie galimybę sukurti nepageidaujamų ịvykių ir gydymo klaidų registracijos sistemą "14, perkèlus ị Lietuvos kontekstą kitose valstybėse skelbtus NI tyrimų duomenis, nustatyta, kad dèl NI prailgèjusios gulëjimo ligoninèje trukmès, mirties ir invalidumo atvejų Lietuvos valstybè kasmet praranda apie 9,2 mlrd. Lt, kas sudaro apie $8,66 \%$ metinio šalies bendrojo vidaus produkto.

Kilęs dèl sisteminių PS trūkumų ir visuomenès tolerancijos ribas peržengęs NI pasireiškimo dažnis, jų sukeliamos turtinès bei neturtinès žalos mastas suteikè impulsą ir paskatino SP sektoriaus, jo organizacijų vadybininkus bei medikus skirti daugiau dèmesio PS, nagrinèti NI pasireiškimo priežastis ir mechanizmus, įgyvendinti PSRV programas.

\section{Tradicinis požiūris ị sveikatos priežiūros sistemą, jos organizacijas, pacientų saugą ir rizikos valdymą}

SP sistema ir SP organizacijos tradiciškai ilgą laiką buvo suprantamos kaip mechaninès, linijiness, statiškos, nuspejjamos ir kontroliuojamos. Šių prielaidų šaknys siekia 17 amžių, kai filosofai suvoke pasaulị kaip „mechaninio laikrodžio mechanizmą “15. Mechanine sistemos samprata, paremta sistemų analizès dedukciniu metodu (nuo bendro prie atskiro, nuo su-

12 Building a safer NHS for patients. Implementing an Organization with a memory [interaktyvus]. 2002 [žiūrèta 2013-12-15]. <http://158.132.155.107/posh97/private/GSP/NHS.pdf>.

13 Nepageidaujami ịvykiai ir jų priežastys sveikatos priežiūros specialistų ir pacientų požiūriu. Higienos institutas, 2008.

14 Analizė apie galimybę sukurti nepageidaujamų îvykių ir gydymo klaidų registracijos sistemą. Galutinè sutarties vykdymo ataskaita [interaktyvus]. Vilnius, 2013 [žiūrèta 2013-12-05] . <http://www.sam.lt/ go.php/lit/>.

15 Wheatley, M. Finding Our Way: Leadership for an Uncertain Time. Berrett-Koehler Publishers (San Francisco, CA),2005. 
dètingo prie paprasto), vadovautasi tiek aiškinantis reiškinius, tiek sprendžiant iškilusias problemas. Techniniai veiksniai (angl. technical factors) ilgą laiką buvo laikomi pagrindine sistemų defektų priežastimi, todèl sistemų patikimumas buvo užtikrinamas tobulinant struktūras ir techninius sprendinius. SPS ir jos organizacijų veiklai apibūdinti plačiai naudotas Donabediano trikomponentis (struktūra, procesas, rezultatas) kokybės modelis. Buvo manoma, kad SP organizacija ar jų grupès (pvz.: organizacijos, teikiančios pirminio, antrinio ar tretinio lygio ambulatorines ar stacionarias ASPP) yra aprūpinamos ištekliais (žmonių, materialiais, finansiniais, kt.), kuriuos tam pritaikyta įstaigų infrastruktūra ịvairiais (klinikiniais, vadybiniais, ūkiniais ir kt.) procesais transformuoja ị prognozuojamus rezultatus geresnę asmens ar visuomenès sveikatos būklę. Tokia „mašinine்“ SP sektoriaus ir SP organizacijos metafora suponavo mechaninị požiūrị ne tik ị jų veiklą, bet ir ị veiklos trūkumus: jeigu sistema (mašina) neveikia, kaip turètų, reikia nustatyti jos defektą (brokuotą ar sugedusią detalę), sutaisyti ją ar pakeisti kita ir sistema (mašina) vèl veiks tobulai.

Mechaninè sistemos ir jos trūkumų samprata suformavo tradicine vadinamą NI priežastingumo teoriją, paremtą tradiciniu požiūriu į žmogaus klaidas (angl. human error), grindžiamu vadinamąja „blogo obuolio“ teorija (angl. bad apple theory), kuri teigia, kad sistemos nesèkmių priežastis yra žmogus, jo padarytos klaidos. Klysta tik „blogi“ žmonès, todèl, juos pašalinus ar pakeitus "gerais“ (neklystančiais), sistema vẻl tampa saugi. Ši NI priežastingumo teorija - žmogaus veiksniu teorija (angl. person approach, human factors theory) ${ }^{16}$ - teigia, kad klaidų priežastis yra žmogaus veiksniai, nes žmogus turi ribotas protines bei fizines galimybes, kurias veikia aplinkos veiksniai. Todèl pabrèžiama, kad pagrindinị dèmesị reikia skirti $\mathfrak{i}$ asmens nuo normos nukrypusius protinius ir fizinius procesus, suponuojančius klaidų atsiradimą, siekiant sumažinti žmogaus elgesio kintamumą. Kadangi klaida sutapatinama su kalte, būtina identifikuoti „kaltą“ asmenį, ji sugėdinti, nubausti, pamokyti ar atleisti už nesugebejjimą veikti saugiai. Todèl tradicinis požiūris ị saugą buvo susijęs su reagavimu ị NI, sutelkiant dèmesị $\mathfrak{i}$ tiesiogines šių ịvykių priežastis - juos sukèlusius darbuotojus bei jų nesaugias veiklas, dažniausiai keliant klausimus: kas padarè? ką padarè? - o ne ieškant atsakymų i klausimus: kodèl tai ịvyko? kodèl nesuveikè saugos barjerai? ką daryti, kad tai nepasikartotų ateityje?

Žmogaus veiksnius sudaro žmogaus fiziologiniai ir psichologiniai, darbo vietos ir aplinkos, žmogaus ir technikos sąsajos bei kiti aspektai. Žmogaus veiksnių tyrinejjimas priskiriamas ergonomikai - mokslo sričiai, nagrinèjančiai žmogaus galimybes ir veiklos trūkumus darbo vietoje. Žmogaus veiksnių tyrinejjimo tikslas - optimizuoti žmogaus ir kitų sistemų sąveiką, siekiant pagerinti jų saugą bei efektyvumą.

JAV civilinès aviacijos îvykių tyrimai parodè, kad $48 \%$ jų yra susiję su organizaciniais, $37 \%$ - su žmogaus, $12 \%$ - su techniniais, $3 \%$ - su kitais veiksniais. Laivininkysteje šie veiksniai sudarè atitinkamai: $53 \%, 24-29 \%, 10-19 \%, 2-4 \%{ }^{17}$. Olandijoje, ištyrus NI ligoninėse priežastis, nustatyta, kad priežastys, susijusios su žmogaus veiksniais, yra vyraujančios ir sudaro 61 \% visų NI priežasčių; nuo pacientų priklausančios priežastys - 39\%, su organizaciniais veiksniais susijusios- 14 \% (organizacinès priežastys lèmė net 93 \% išvengiamų NI pasireiškimą), su techniniais veiksniais $-4 \%{ }^{18}$. Šie ir daugelis kitų mokslinių tyrimų parodè, kad

16 Reason, J. Human error: models and management. BMJ. 2000, 320: 768-770.

17 Johnson, C. W.; Holloway, C. M. A Longitudinal Analysis of the Causal Factors in Major Maritime Accidents in the USA and Canada (1996-2006). Proceedings of the 15th Safety-Critical Systems Symposium. Bristol, UK. The Safety of Systems. 2007, 85-94.

18 Smits, M., et al. Exploring the causes of adverse events in hospitals and potential prevention strategies. Quality and Safety in Health Care. 2010, 19(5): e5. 
kituose ūkio sektoriuose veikiančiose sudètingose organizacijose Nİ sukèlusios priežastys yra dažniausiai nulemiamos ne tik žmogaus, bet ir kitų veiksnių. Pastebėta, kad sudètingoms sistemoms yra būdingas netikètai pasireiškiantis (emergentinis) elgesys, kurio negalima paaiškinti ir aprašyti ịprastais priežasties-pasekmès ryšiais. Be to, „gyvos sistemos“ tapačiose situacijose gali elgtis skirtingai, o identiškos intervencijos panašiose situacijose gali sukelti skirtingus (neprognozuotus) rezultatus. Todèl, analizuojant sudètingas sistemas, kurioms priklauso ir SP organizacijos, bei planuojant intervencijas, būtinas visuminis kompleksinis požiūris.

\section{Kompleksinis požiūris ị sveikatos priežiūros sistemą ir jos organizacijas, pacientų saugą ir rizikos valdymą}

Kompleksinèms sociotechninèms sistemoms priskiriamose pramonès srityse, kurioms būdingi sudètingi ir įvairiapusiai santykiai bei sąryšiai tarp žmonių, jų atliekamų veiklų, techninių sistemų, organizacijų ir aplinkos, - žalingi veiksniai ir jų poveikis sistemoms nagrinejjami pasitelkiant ịvairius modelius. Vienas labiau paplitusių - PĮAŽŽZ̆ (Procedūros, İrankiai, Aplinka, Žmogus, Žmonès) (angl. SHELL - Software, Hardware, Environment, Liveware and Liveware) modelis, sèkmingai naudojamas aviacijoje atvaizduojant ir analizuojant ịvairių sistemos elementų tarpusavio sąveikas (žr.1 pav.):

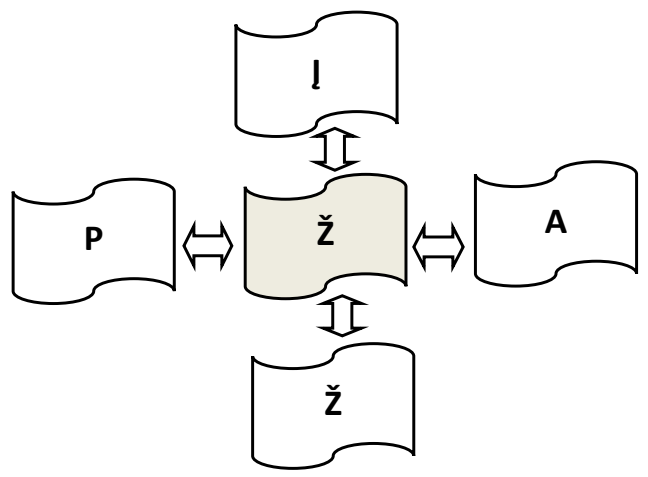

1 pav. PİAŽ (Procedūros, İrankiai, Aplinka, Žmogus, Žmonès) modelis ${ }^{19}$

Šaltinis: Stolzer, A. J.; Halford, C. D.; Goglia, J. J. Safety Management Systems in Aviation. Ashgate Studies in Human Factors for Flight Operations. Burlington: Ashgate Publishing Company, 2013.

PĮAŽ modelis pritaikomas ir sveikatos priežiūroje tyrinejjant žmogaus veiksnius ir jų poveikị sistemoms. Centrinè modelio figūra yra žmogus (centrinė figūra „Ž “), îvairiapusiai sąveikaujantis bei susijęs su kitais funkcionuojančiais sistemos elementais („I“, „A“, „Ž „P“). Naudojant šį modelị ịvertinami žmogaus fiziniai, fiziologiniai, psichologiniai ir psichosocialiniai veiksniai, jų sąveika bei įtaka kitiems sistemos elementams:

(a) $\check{Z}$ - I sąryšyje (angl. Liveware - Hardware) vertinama SP specialisto sąveika su medicinos ir laboratorine įranga, kompiuteriais, kt.;

19 Stolzer, A. J.; Halford, C. D.; Goglia, J. J. Safety Management Systems in Aviation. Ashgate Studies in Human Factors for Flight Operations. Burlington: Ashgate Publishing Company, 2013. 
(b) $\check{Z}$ - P sąryšyje (angl. Liveware - Software) vertinama SP specialisto sąveika su procedūromis, taisyklèmis, saugos patikros kontroliniais lapais, kompiuterinèmis programomis, kt.;

(c) Ž - A sąryšyje (angl. Liveware - Environment) įvertinamas SP specialisto darbui ịtakos turinčios vidinès (fizinès aplinkos, darbo sąlygų, darbo režimo, vadovybès sprendimų) bei išorinès (teisinès, kultūrinès, ekonominès, socialinės, kt.) aplinkos (konteksto) poveikis;

(d) $\check{Z}$ - Ž sąryšyje (angl. Liveware - Liveware) - ịvertinama SP specialisto sąveika su kitais žmonėmis: gydytojo - paciento, gydytojo - slaugytojo, gydytojo - sveikatos priežiūros specialistų komandos, ASPI vadovybès - SP specialistų, ASPI darbuotojų kontrolès funkcijas atliekančių tarnybų darbuotojų, kt.

Adaptuotas PİŽ (angl. Sunflower - SHELL) modelis taikomas tyrinejjant žmogaus veiksnius ir jų poveikị ligoninèse ${ }^{20}$.

Tačiau žmogaus veiksnių priežastingumo teorija nagrinèjant nesèkmių priežastis sudètingose sociotechninèse organizacijose pasirodè esanti nepakankama, nes fragmentiniai „defektuotų“ struktūrų pataisymai, pakeitimai ar pašalinimai dažnai neatneša laukiamų (prognozuotų) rezultatų. Nagrinejjant sudètingas organizacijas tradicinę sistemų teoriją, kurios pagrindą sudarè „negyvybingų sistemų“ mechaninè analizé, pakeite் „gyvo organizmo sistemos" metafora pagrịsta moderni kompleksinès prisitaikančios sistemos teorija (angl. complex adaptive system theory), pabrèžusi sistemos (rinkinio erdvejje ir laike veikiančių, tarpusavio ryšiais susietų elementų, siekiančių bendrų tikslų) kompleksiškumą (didelę ìvairovę ją sudarančių elementų ir ryšių tarp jų) bei prisitaikomumą (gebejimą prisitaikyti prie kintančios aplinkos ir mokytis iš praeities).

Kilęs iš fizikos, matematikos ir biologijos kompleksiškumo mokslas (angl. complexity science) išsiplète ir ị vadybos, SP sritis. Rinka, ekosistema, socialinè sistema, politinè sistema, žmogus, jo imunine sistema, SP sistema, SP ịstaiga - šios ir daugelis kitų mus supančių sistemų priskiriamos kompleksinėms prisitaikančioms sistemoms. Žmogaus sveikata yra rezultatas kompleksinių procesų, veikiančių tarpusavyje sąveikaujančių sudėtingų sistemų. Žmogaus sveikatos problemų tikrąsias priežastis ir jų pasireiškimo mechanizmus, kaip ir žmogaus elgesí, turintị ịtakos jo sveikatai, yra sudètinga nuspèti. $\mathrm{O}$ ir pati sveikatos priežiūra tampa vis kompleksiškesné, daugiaaspekte் ${ }^{21}$. Todèl mūsų mąstysena apie žmonių sveikatą, jos problemas ir sveikatos priežiūrą turi atspindèti šį kompleksiškumą ${ }^{22}$.

Kompleksinis požiūris ị SP sistemą ir jos organizacijas suformavo modernų požiūrị i žmogaus klaidas, grindžiamą sisteminių trūkumų teorija. Ši teorija teigia, kad žmogui yra būdinga klysti ir žmogaus klaidos nèra atsitiktinès ar retos, jos atsitinka nuolat. Problemos kyla ne iš žmonių, bet iš sistemų, o žmogaus klaida yra ne NI priežastis, bet simptomas giliau esančių sisteminių (latentinių) problemų. Nİ j̣vyksta esant situacijoms, kai sumiškai veikiantys keli nepalankūs veiksniai sustiprina vienas kitą ir praeina pro susilpnejusius sistemos apsauginius barjerus. Siekiant užkirsti kelią klaidoms pasireikšti Nİ, būtina spręsti gilesnius, dažnai latentinès fazès sisteminius trūkumus, stiprinti sistemos apsauginius barjerus. Kadangi žmogaus klaidos yra neišvengiamos, jos neturi būti tapatinamos su kalte, nes tokiu atveju jos bus slepiamos, iš jų nesimokoma.

20 Takayanagi, K.; Hagihara, Y. Revised sunflower - SHELL model - an analysis tool to ensure averse events' factor analysis and followed by patient safety strategy. Jpn Hosp. 2007, Jan (25): 11-18.

${ }_{21}$ Plsek, P. E.; Greenhalgh, T. Complexity science: The challenge of complexity in health care. BMJ. 2001, 323: 625-628.

22 Lee, R. C.; Donaldson, C.; Cook, L. S. The need for evolution in healthcare decision modeling. Medical Care. 2003, 41(9): 1024-1033. 
Moderni NI priežastingumo teorija - sisteminiu veiksnių teorija (angl. systems approach, system factors theory) - akcentuoja ne žmogaus asmenines savybes, bet jo veiklos sąlygas, aplinką. Klaidos - sisteminių defektų (ydų) požymis, o ne asmenybės (charakterio) defektų požymis. Ši teorija teigia, kad NI j̇vyksta dažniausiai susisumavus latentiniams (atsiradusiems dèl sisteminių veiksnių) ir aktyviems (atsiradusiems dèl žmogaus veiksnių) faktoriams bei susilpnèjus sistemų apsauginiams barjerams. Sisteminių veiksnių priežastingumo teoriją aprašè J. Reason „Šveicariško sūrio“ modelyje ${ }^{23}$ (žr. 6 pav.). Aiškinantis įvykusio NI priežastis svarbu ne tai, kas suklydo, bet kodèl nesuveikè sistemos apsauginiai barjerai ir saugikliai, neužkirto kelio žalingam veiksniui tapti nepageidaujama pasekme.

Organizacinių sistemų tyrinètojai pabrèžia, kad SP sektorius ir jo organizacijos yra vienas sudètingiausių. Tai lemia daugelis faktorių, iš kurių paminètini: (1) SP objektas (pacientas) pati savaime yra kompleksinè sistema, kurios funkcionavimas priklauso nuo daugybès veiksnių (kintamųjų), kurie nèra visiškai ištirti (pvz.: ligų genetinè predispozicija, gyvensenos bei aplinkos faktorių įtaka sveikatai, kt.), yra kintantys ir ne visuomet nuspejami (pvz.: žmogaus elgsena, individualūs motyvatoriai, kt.); (2) SP intervencijos ị paciento sveikatą yra kompleksinio sociotechninio pobūdžio (pvz.: medikų atliekamos sudètingos diagnostinès ir intervencinès instrumentinès procedūros, skiriamų vaistų suderinamumas pacientui sergant keliomis ligomis, medikų komandinio darbo pobūdis (operacinèse, konsiliumuose, kt.) ir pan.), reikalauja sudetingų santykių tarp SP darbuotojų, jų komandų ir paciento, bei SP specialistų sąveikos su medicininėmis ir informacinèmis technologijomis; (3) sparčiai vykstantys išorinès ir vidinès aplinkos pokyčiai (pvz.: medicinos technologijų ir farmacijos inovacijos ir plètra, SP sektoriaus teisiniai ir organizaciniai pokyčiai; didejantys visuomenès poreikiai SP ir SP paslaugų kokybei esant ribotiems ištekliams; sveikatos priežiūros globalizacija, kt.). Šie ir daugelis kitų veiksnių suponuoja ypač sudetingą SP sektoriaus organizacijose dirbančių specialistų veiklos pobūdị.

SP sektorius ir jo organizacijos yra priskiriamos sociotechninèms sistemoms, pabrèžiant socialinių (žmonių grupių, komandų, visuomenès) ir techninių (technologijų, infrastruktūrų, įrenginių, procesų, kt.) aspektų sąveikos kintančios aplinkos kontekste svarbą. Sociotechninès sistemos terminą pasiūlè ir koncepciją pateikè $1951 \mathrm{~m}$. E. Trist ir K. Bamforth Jungtinès Karalystès Tavistock institute, sujungę iki tol atskirai nagrinètus socialinius ir techninius sudètingų organizacijų aspektus ị vientisą sistemą, pabrěždami jų tarpusavio sąveikos svarbą ${ }^{24}$, nes, siekiant organizacijos tikslų, izoliuotos intervencijos ị vieną iš šių aspektụ (socialinị ar techninị) neatnešdavo laukiamų rezultatų. Sociotechninių sistemų teorinị pagrindą sudaranti sociotechniné teorija (angl. sociotechnical theory) teigia, kad organizacijose socialiniai ir technologiniai elementai veikia glaudžiai tarpusavyje susiję ir sąveikaudami: (1) paprastais nuspejjamais linijiniais (priežasties-pasekmès) ryšiais, kurie organizacijose struktūromis ir procesais yra tikslingai projektuojami, siekiant užsibrěžtų tikslų bei planuojamų rezultatų, bei (2) sudètingais (kompleksiniais) sunkiai nuspejjamais, todèl dažnai neprojektuojamais, nelinijiniais ryšiais, suponuojančiais šalutinių (neplanuotų) teigiamo ar neigiamo pobūdžio rezultatų atsiradimą. Veikiant tik vieną iš aspektų (socialinị ar techninị), tikètinas sunkiai nuspejjamų kompleksinių nelinijinių ryšių, kurie gali neigiamai paveikti organizacijos veiklą, susiformavimas. Todèl planuojant ir igyvendinant pokyčius organizacijose (pvz.: keičiant struktūras, pertvarkant procesus, diegiant naujas technologijas, kt.) būtinas kompleksinis ir koordinuotas, abu komponentus (socialinị ir techninị) apimantis požiūris.

23 Reason, J. 2000, supra note 16, p. 768-770.

24 Davis, M. C., et al. Advancing socio-technical systems thinking: A call for bravery. Applied Ergonomics. 2014, 45 (2): 171-180. 
Mokslineje literatūroje SP sektorius, SP organizacijos yra nurodomos kaip ypatingai kompleksinès (superkompleksinès) adaptacinès sociotechninės sistemos (žr. 1 lentelę).

Kompleksiškumo mokslas nagrinèja sudètingų adaptacinių sistemų elgseną, kuri priklauso nuo sistemos elementų ịvairovès, jų tarpusavio ryšių tinkliškumo ir sąveikos laipsnio. Kompleksiškumo sritis yra apibūdinama kaip sritis, kurioje yra mažas techninis nuspejamumas ir aiškumas bei mažas socialinis nuspejjamumas ir sutarimas dẻl tikslų, procesų, rezultatų. Pagal socialinę ir technologinę dimensijas, ịvertinus sistemos elementų sąveikos nuspejjamumą, sutarimo dèl tikslų, procesų ir rezultatų lygị, taip pat atsižvelgiant ị sistemų sudètingumo laipsnị (elementų, užduočių, funkcijų skaičių), sistemos skirstomos ị: (1) paprastas sistemas (angl. simple systems), (2) komplikuotas (sudètingas) socialines sistemas (angl. complicated social systems), (2) komplikuotas (sudetingas) technines sistemas (angl. complicated technical systems) bei (4) kompleksines (sudetines) sociotechnines sistemas (angl. complex sociotechnical systems) (žr. 2 pav.):

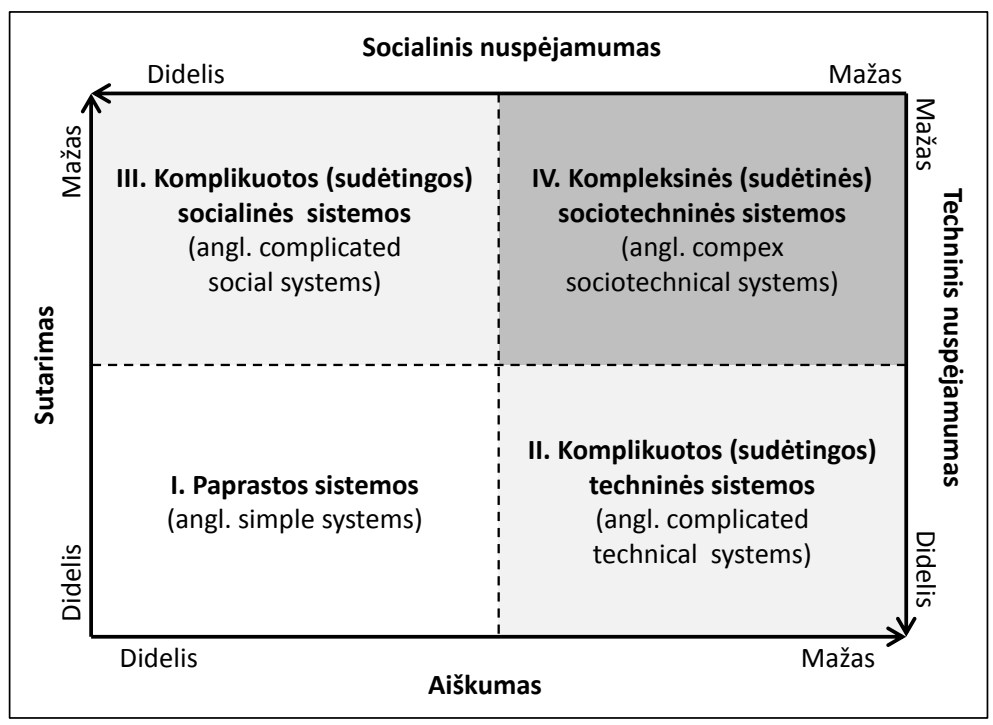

2 pav. Sistemų klasifikacija pagal socialinį-technologinị sudètingumą (adaptuota pagal Kanados ịvykių analizès schemą) ${ }^{25}$

Šaltinis: Canadian Incident Analysis Framework. 2012. Canadian Patient Safety Institute [interaktyvus]. 2012 [žiūrèta 2013-12-21]. <http://www.patientsafetyinstitute.ca>

P. E. Plsek, T. Wilson ir T. Greenhalgh ${ }^{26}$ - vieni iš pirmųjų pateikè iki tol vyravusiai mechaninei (mašininei) SP sektoriaus metaforai alternatyvią - kompleksinés prisitaikančios sistemos (angl. complex adaptive system) koncepciją, ją apibūdindami kaip rinkinị laisvai, bet ne visuomet nuspèjamai veikiančių veikëjų (agentų), kurių veiksmai yra tarpusavyje susiję

25 Canadian Incident Analysis Framework. 2012. Canadian Patient Safety Institute [interaktyvus]. 2012 [žiūrèta 2013-12-21]. <http://www.patientsafetyinstitute.ca>.

26 Plsek, P. E.; Wilson, T. Coplexity science. Complexity, leadership, and management in healthcare organizations. BMJ. 2001, 323: 746-749. 
taip, kad vieno veikejjo elgsenos pokytis pakeičia kitų veikejų veiklos aplinką (kontekstą), taip netiesiogiai darant ịtaką jų veiklai. Kaip pastebi šie autoriai, kompleksinèse prisitaikančiose sistemose ryšiai ir sąveikos tarp jų elementų dažnai yra daug svarbesni negu pavienių sistemos elementų veikla ir generuojami rezultatai. Būtent ryšiai tarp elementų ir jų tarpusavio sąveika lemia kompleksinių adaptacinių sistemų naujai iškylančias (emergentines) elgsenas, galimybes ir savybes, kurių neturi atskiri šių sistemų elementai. Be to, negyvos „mechaninès“ sistemos ribos paprastai yra aiškiai apibrěžiamos ir nuspejjamos, tuo tarpu "gyvos" adaptacinès sistemos ribos dažnai yra neaiškios, jos veikejjai dažnai priklauso ne vienai, o kelioms sistemoms, yra kintantys, migruojantys, keičiantys taisykles. Kadangi veikejjai kompleksinèje sistemoje turi gebejimų keistis ir keisti sistemos elgseną, kompleksinè sistema turi svarbią savybę - sugebejjimą išlaikyti pusiausvyrą su aplinka, prisitaikant prie jos pokyčiu (adaptacinè funkcija). Todèl kompleksinè sistema, siekdama užsibrèžtų tikslų ir pusiausvyros su kintančia aplinka, yra nuolatinès dinaminès būsenos, transformacijos procese.

Anksčiau vyravusi mechaninè organizacijų sistemų samprata lèmé vadybininkų norą kontroliuoti organizacijas kaip mašinas, standartizuoti jų veiklą netoleruojant nuokrypių, kurie laikytini nepageidaujamais. Šiuo požiūriu buvo vadovaujamasi organizacijose diegiant atitikties nustatytiems standartams užtikrinimu paremtas kokybės vadybos sistemas (pvz.: kokybės kontrolès (angl. quality control), kokybès užtikrinimo (angl. quality assurance), kt.). Tačiau nuodugnesnè sudètingų sistemų analizè atskleidè, kad variacijos ir nuokrypiai yra savaime užprogramuoti pačioje nuolat kintančioje (dinaminejje) kompleksinèje prisitaikančioje sistemoje, vykstant dinaminèms sąveikoms tarp daugelio skirtingų kintančių veiksnių, ir yra būtini adaptuojantis sistemai prie kintančios vidinès ir išorinès aplinkos, būdami pokyčiu ir inovacijų pagrindu. Dinaminis sistemų pobūdžio suvokimas paskatino organizacijas diegti nuolatinio tobulëjimo siekimu paremtas kokybès vadybos sistemas (pvz.: nuolatinio kokybès gerinimo (angl. continuous quality improvement), Europos kokybès vadybos fondo tobulumo modelis (angl. The European Foundation for Quality Management Excellence Model), kt.). Tačiau nuokrypiai, peržengę leistinas tolerancijos ribas, gali sukelti ir nepageidaujamus padarinius, todèl būtina aiškiai apsibrèžti ir sutarti dèl leistinų veiklos nuokrypio ribų.

Šių dviejų požiūrių ì sistemas (mechaninio, linijinio, uždaro, statiško ir kompleksinio prisitaikančio, atviro, dinaminio) egzistavimas SP sektoriuje sukelia SP specialistams ir vadybininkams sudètingą dilemą: užtikrinti, kad pacientams teikiant SPP būtų laikomasi mokslo įrodymais pagrịstų medicinos ir slaugos praktikos standartų (siekiant standartizuoti, generalizuoti sveikatos priežiūrą), kartu užtikrinant individualiems konkretaus paciento poreikiams pritaikytą sveikatos priežiūrą (siekiant personifikuoti, individualizuoti sveikatos priežiūrą). Šią dilemą nagrinèjo S. Bar-Yam su bendraautoriais ${ }^{27}$, atkreipdami dèmesị i tai, kad klaidos ir NĮ SP sistemoje pasireiškia ir dèl ydingo veiklos organizavimo. Efektyvus veiklos organizavimas yra susijęs su užduočių mastu (pasikartojimo dažniu) ir kompleksiškumu (įvairove). Kai organizacijoms, sukurtoms (skirtoms) kompleksinèms sudètingoms užduotims vykdyti, pavedama atlikti daug paprastų (nesudètingų) užduočių, susiduriama su jų veiklos neefektyvumu. Kai organizacijoms, skirtoms didelio masto rutininėms užduotims vykdyti, pavedamos atlikti kompleksinès užduotys, susiduriama su suboptimalia jų veikla, klaidomis. Todèl, pasak autorių, yra tikslinga sveikatos priežiūrą santykinai skirstyti ị dvi sritis: (1) paprastos priežiūros (angl. simple care) - kuri gali būti standartizuota daugeliui pacientų (pvz.: sveikatos patikrinimai, vakcinacija, iprasti laboratoriniai ir rentgeno tyri-

27 Bar-Yam, S., et al. A Complex Systems Science Approach to Healthcare Costs and Quality. New England Complex Systems Institute [interaktyvus]. USA, 2012 [žiūrèta 2013-12-28]. <http://www.necsi.edu/ research/management/health $>$. 
mai, nesudètingos chirurginès operacijos, kt.), bei (2) kompleksinès priežiūros (angl. complex care) - kuri yra sudètinga, skirtinga ir individuali kiekvienam pacientui (pvz.: kompleksiné ligų diagnostika ir gydymas, sudėtingos chirurginès operacijos, kt.). SP sistema bus efektyvesnè ir saugesnè, pavedus rutininę (standartizuojamą) SP vykdyti organizacijoms, orientuotoms ị veiklos mastą, o sudètingą (personifikuotą) SP - organizacijoms, orientuotoms $\mathfrak{i}$ veiklos kompleksiškumą.

SP sistemai ir jos organizacijoms būdingas sociotechninis kompleksiškumas (mažas socialinis ir techninis nuspejjamumas); atvirumas (funkcionavimas yra glaudžiai susijęs ir priklauso nuo aplinkos); heterogeniškumas (tarpusavyje susiję, tačiau skirtingi komponentai (žmogiškieji, materialūs, informaciniai, procedūrų, kt.), veikiantys kartu, papildantys vienas kitą). A. Hobbs su bendraautoriais ${ }^{28}$ tyrinėdamas sociotechninių sistemų integralumo klausimus, pateike adaptuotą pagal H. R. Booher sociotechninių sistemų kompleksiškumo klasifikaciją, išranguodami jas nuo paprastų, sudarytų iš ịrenginių (prietaisų) ir sistemos dalių, iki ypač sudėtingų, veikiančių nenuspejjamoje ar sunkiai nuspejjamoje aplinkoje (žr. 1 lentelę):

1 lentelè. Sociotechninių sistemų kompleksiškumo lygiai ${ }^{29}$

\begin{tabular}{|c|c|c|c|c|}
\hline & \multirow[b]{2}{*}{ Sociotechninè sistema } & \multicolumn{3}{|c|}{ Sritis } \\
\hline & & $\begin{array}{l}\text { Sveikatos } \\
\text { priežiūra }\end{array}$ & Transportas & Energetika \\
\hline A. & $\begin{array}{l}\text { Ypatingai kompleksinès organizacijos (angl. } \\
\text { very highly complex organizations) }\end{array}$ & $\begin{array}{l}\text { Nacionalinè svei- } \\
\text { katos sistema }\end{array}$ & NASA & $\begin{array}{l}\text { JAV Energetikos } \\
\text { departamentas }\end{array}$ \\
\hline B. & $\begin{array}{l}\text { Labai kompleksinès organizacijos (angl. } \\
\text { higly complex organizations) }\end{array}$ & Ligoninè & $\begin{array}{l}\text { Nacionaline } \\
\text { kosmonautikos } \\
\text { sistema }\end{array}$ & $\begin{array}{l}\text { Branduolinès } \\
\text { energetikos } \\
\text { komisija } \\
\end{array}$ \\
\hline C. & $\begin{array}{l}\text { Kompleksinès organizacijos (angl. complex } \\
\text { organizations) }\end{array}$ & $\begin{array}{l}\begin{array}{l}\text { Skubios pagalbos } \\
\text { skyrius }\end{array} \\
\end{array}$ & Orlaivis & $\begin{array}{l}\text { Atominè } \\
\text { elektrinè }\end{array}$ \\
\hline D. & $\begin{array}{l}\text { Didžiosios technologinès sistemos (angl. } \\
\text { major technological systems) }\end{array}$ & $\begin{array}{l}\text { Magnetinio rezo- } \\
\text { nanso tomogra- } \\
\text { fijos aparatas }\end{array}$ & $\begin{array}{l}\text { ATC kontrolès } \\
\text { centras }\end{array}$ & $\begin{array}{l}\text { Kontrolès } \\
\text { kambarys }\end{array}$ \\
\hline E. & $\begin{array}{l}\text { Kritinès technologinės posistemès (angl. } \\
\text { critical technological subsystems) }\end{array}$ & $\begin{array}{l}\text { Monitoriaus } \\
\text { ekranas }\end{array}$ & ATC konsolè & $\begin{array}{l}\text { Kontrolè / } \\
\text { displèjus }\end{array}$ \\
\hline F. & $\begin{array}{l}\text { Irenginiai ir sistemos dalys (angl. Devices } \\
\text { and system parts) }\end{array}$ & Kateteris & Skrydžio takas & Vandens pompa \\
\hline
\end{tabular}

Šaltinis: Hobbs, A., et al. 2008. Three principles of human-system integration. Proceedings of the 8th Australian Aviation Psychology Symposium [interaktyvus]. Sydney, Australia, 2008 [žiūrèta 2013-12-28]. $<$ http://humansystems.arc.nasa.gov/publications/3Principles_HSI.pdf>

Šioje sociotechninių sistemų klasifikacijoje nacionalinè sveikatos priežiūros sistema priskiriama ypatingai kompleksinèms, o ASPI (ligoninè) - labai kompleksinèms organizacijoms.

Inovatyvūs veiklos modeliai, vadybos sistemos, produktai ir paslaugos, nuolat vykstantys struktūriniai ir funkciniai pokyčiai padeda SP organizacijoms prisitaikyti prie vidinès ir išorinès aplinkos pokyčių, didinti veiklos efektyvumą bei gerinti teikiamų SPP kokybę. Tačiau

28 Hobbs, A., et al. 2008. Three principles of human-system integration. Proceedings of the 8th Australian Aviation Psychology Symposium [interaktyvus]. Sydney, Australia, 2008 [žiūrèta 2013-12-28]. <http:// humansystems.arc.nasa.gov/publications/3Principles_HSI.pdf>.

Ibid. 
šie pokyčiai sukelia naujas ar kitokias sistemines spragas, generuoja naujas rizikas. Iškilusiems naujiems pavojams numatyti, jiems išvengti ar sumažinti jų keliamą riziką bei neigiamus padarinius būtinas sisteminis kompleksinis dinaminis požiūris ị PSRV SP organizacijose.

Kompleksinių sistemų, kurioms priskiriamos ir SP organizacijos, rizikos dažnai taip pat yra kompleksinio (ne linijinio) pobūdžio ir turi būti valdomos sistemiškai, ịvertinant sistemos dedamąsias ir jų tarpusavio sąveikas, o ne tik kiekvieno sistemos komponento riziką atskirai, nekreipiant dèmesio ị jų tarpusavio ryšius. Kaip kiekviena intervencija ị kompleksinę sistemą veikia visą sistemą, taip ir pati sistema veikia kiekvieną intervenciją. Kompleksinèse sistemose valdant riziką izoliuotai, veikiant vieną sistemos grandị ar elementą, poveikis gali pasireikšti nebūtinai tiesiogiai, kaip tikimasi, bet paveikiant per glaudžius ryšius kitus sistemos elementus, kas gali sukelti tolesnį kitos rizikos atsiradimą. Todèl ASPĮ veiklos ir rizikos poveikio kompleksiškumo supratimas yra labai svarbus, renkantis PSRV metodus ar priemones.

Moksliniai tyrimai rodo, kad daugiau kaip 50 \% NI galima išvengti, jeigu jie būtų tinkamai valdomi. Tam būtinas sisteminis požiūris ị PSRV, apimantis SPP teikimo aplinkos esminius pokyčius: (1) teisinės aplinkos (žalos atlyginimo esant ASPİ ar jos darbuotojo kaltei (ieškinio modelio) keitimas žalos atlyginimo be kaltés modeliu); (2) saugos kultūros (angl. safety culture) puoselejimas; uždaros, pacientų saugos ịvykius (PSIt) slèpti skatinančios, baime, kalte ir bausmèmis paremtos įvardijimo, kaltinimo ir gèdinimo (baudimo) kultūros (angl. name,blame and shame (punitive) culture) keitimas atvira teisinga ir sąžininga (nebaudimo) kultūra (angl. just and fair (non-punitive) culture), motyvuojančia SP organizacijų darbuotojus registruoti Nț, iš jų mokytis; (3) technologinès aplinkos (diegiant su PS susijusius e. produktus: PSİ e. registravimo (privalomo, savanoriško) sistemas (nacionalines, lokalias), klinikinių sprendimų palaikymo e. programas, e. sveikatos (ligos) istorijos, e. recepto, kt.) pokyčius.

Sisteminé sociotechninių organizacijų samprata padeda suvokti PSRV intervencijų diegimo ypatumus SP ịstaigose.

\subsection{Sociotechninès sveikatos priežiūros sistemos lygmenys ir jų svarba diegiant PSRVS}

Sisteminiu požiūriu nagrinèjant SP sektorių, dauguma autorių pateikia keturių lygmenų SP sistemos stratifikaciją: trys vidiniai (organizacijos vidaus) ir vienas išorinis (už organizacijos ribų) $)^{30}$. Sisteminiu požiūriu tyrinejjant PSRV kompleksinèje sociotechninèje SP sistemoje, tikslinga joje išskirti 5 lygmenis (žr. 3 pav.):

1. Mikrosistemos (klinikinés) - SPP transakcijos tarp SP paslaugos teikejjo (gydytojo, slaugytojo, kt.) ir SP paslaugos gavejo (paciento) lygmuo;

2. Mezosistemos - ASPI struktūrinio ar funkcinio padalinio, teikiančio tam tikros srities SP paslaugas (pvz.: intensyvios terapijos skyrius, radiologijos departamentas, operacinè, kt.), lygmuo;

3. Makrosistemos - ASPĮ, sujungiančios ịvairius (klinikinius, neklinikinius) padalinius, lygmuo;

4. Megasistemos - SP sektoriaus (reguliavimo, kontrolès, licencijavimo, sertifikavimo, akreditavimo ir kitos ASPI veiklai poveikị darančios SPS organizacijos); švietimo ir mokslo institucijos, rengiančios ir tobulinančios SPS; SPS profesinès sąjungos, specialybės draugijos ir pan. lygmuo;

5. Metasistemos - savivaldybès, valstybès, visuomenès, t. y. sistemų, esančių už megasistemos ribų, lygmuo.

30 Nelson, E. C., et al. Clinical microsystems, part 1. The building blocks of health systems. Joint Commission Journal on Quality and Patient Safety. 2008, 34(7): 367-378. 


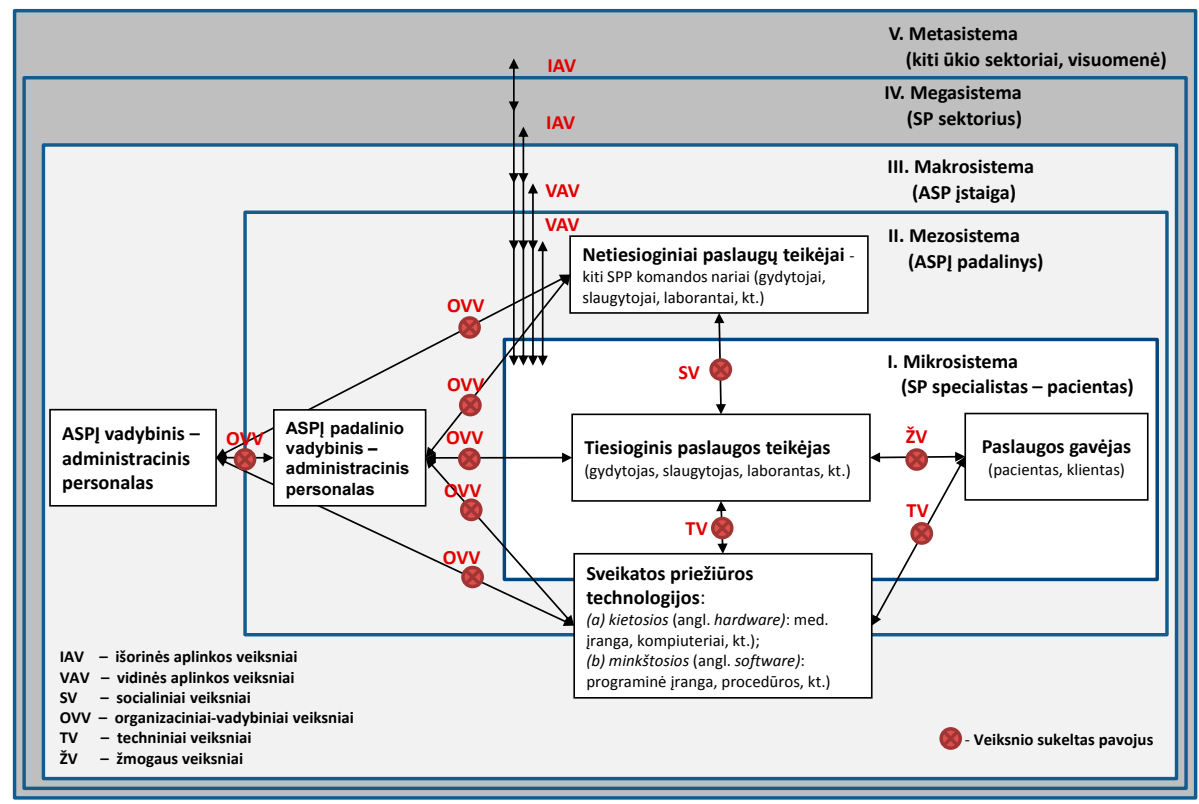

3 pav. Kompleksinès sociotechninès sveikatos priežiūros sistemos rizikos veiksnių poveikio schema (sudaryta autoriaus)

Visus šiuos SP sistemos lygmenis savo ruožtu sudaro atviros dinaminès sistemos. Žemesnio lygmens sistema yra veikiama ir priklausoma nuo aukštesnio lygmens sistemos, kartu būdama aukštesnio lygmens sistema dar žemesnio lygmens subsistemai. SP sistemoje visi šie lygmenys funkcionuoja ne atskirai, bet yra glaudžiai tarpusavyje susiję daugybiniais ryšiais ir yra priklausomi vieni nuo kitų. Todèl kuriant bei diegiant PSRVS SP sektoriuje bei jo organizacijose, būtina ịvertinti ì kurị lygmenị (nacionalinị, savivaldos, ASPI , ASPI padalinio ar SP paslaugų teikimo) ji bus nukreipta. Pavyzdžiui, diegiant PSRVS ASPI radiologijos padalinyje, būtina suprasti šio mezosistemos lygmens veiklos principus bei sąveiką su kitais organizacijos viduje esančiais sistemos sluoksniais: mikrosistemos (pvz.: radiologų klinikinès komandos), mezosistemos (pvz.: intensyvios pagalbos ar traumatologijos skyriumi) bei už ASPI esančiais megasistemos (pvz.: Radiacinès saugos centru, kt.) sluoksniais. Būtina ịtraukti į PSRVS projektavimą, konstravimą ir diegimą atitinkamo lygmens (lygmenų) darbuotojus. Išvysčius PSRVS mezosistemos (ASPI padalinio) lygmeniu, ji gali būti toliau adaptuota kitoms mezosistemoms (kitų ASPI radiologijos padaliniams) ar kitiems tos pačios ASPI padaliniams - mezosistemos ar makrosistemos lygmeniui. Tačiau būtina atkreipti demesi ji tai, kad skirtingose SP organizacijose yra savita vidinè aplinka (organizacinè ir saugos kultūra, kokybės vadyba, sprendimų priemimas, NI valdymas, kt.), susiformavę skirtingi ryšiai ir sąveikos mechanizmai tarp sistemos lygmenų gali skirtis, todèl būtinas diegiamų PSRVS adaptavimas. 


\section{Ivykių modeliai, jų samprata ir evoliucija}

Ivykių modelių koncepcijos istoriškai buvo nagrinèjamos ịvairių sričių (inžinerijos, kognityvinès psichologijos, sociologijos, vadybos, kt.) atstovų. Kaip pažymi Z. H. Qureshi' ${ }^{31}$, i̇vykių modeliai suteikia informaciją apie ịvykius, parodydami ryšius tarp priežasties ir pasekmès. Tradiciškai, kaip nurodo autorius, ịvykiai buvo suprantami, kaip grandinė nesèkmių, kurių kiekviena - pasekmè prieš tai buvusios priežasties. Todèl NĮ analizès ir rizikos vertinimo technikos buvo paremtos linijine (vienalinijine, daugialinijine) ịvykių priežastingumo samprata, kuri pasirodè esanti nepakankama modeliuojant ir analizuojant modernias kompleksines sistemas, jų veiklos problemas. Skirtingai nei tradicinès techninès inžinerinès sistemos, modernios kompleksinės sistemos yra sudarytos iš daugybės skirtingų veikẻjų: socialinių institucijų, žmonių, technologijų, kt. Tokiose sociotechninèse sistemose elementai yra glaudžiai tarpusavyje susiję ne linijinio, bet tinklinio pobūdžio ryšiais (tiesioginiais, lateraliniais, atgaliniais, kt.). Dèl kompleksinio požiūrio ị sistemą sampratos evoliucijos ịtakos ịvykių modeliai istoriškai evoliucionavo nuo nuoseklios sekos (linijinių) (angl. sequential (event-based) accident models) i epidemiologinius (angl. epidemiological accident models) ir pastaruoju metu vis plačiau taikomus - sisteminius įvykių modelius (angl. systemic accident models) (žr. 4 pav.).

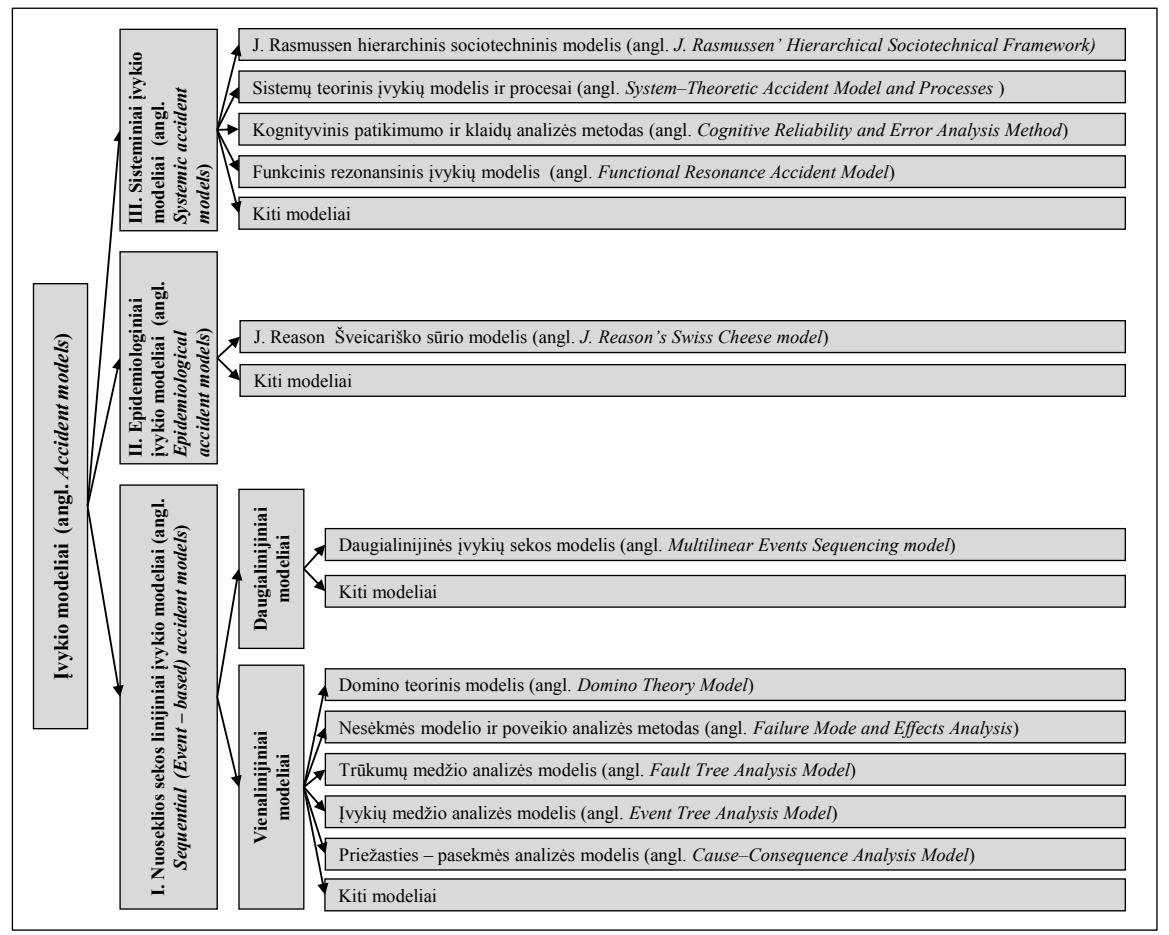

4 pav. Ivykio modelių taksonomijos schema (susisteminta ir adaptuota pagal Z. H. Qureshi ${ }^{32}$ )

Šaltinis: Qureshi, Z. H. A Review of Accident Modelling Approaches for Complex Critical Sociotechnical Systems. Technical Report 2008.

31 Qureshi, Z. H. A Review of Accident Modelling Approaches for Complex Critical Sociotechnical Systems. Technical Report. 2008.

32 Qureshi, Z. H., supra note 31. 
Išskiriami trys „klasikiniai“ šias NI modelių evoliucijos pakopas charakterizuojantys Ł̇vykių modeliai: Domino teorinis modelis (linijinis), J. Reason „Šveicariško sūrio“ modelis (epidemiologinis) ir J. Rasmussen Hierarchinis sociotechninis modelis (sisteminis).

Domino teorinis modelis, kurị $1931 \mathrm{~m}$. aprašè H. W. Heinrich ${ }^{33}$, pateikiamas kaip klasikinis nuoseklios sekos vienalinijinis NI modelis, paremtas domino j̣vykių priežastingumo teorija, pabrěžiančia žmogaus klaidos svarbą. Pagal šią teoriją nelaimingą atsitikimą (pasekmę) (angl. accident) sukelia atskiri veiksniai, nuosekliai einantys vienas po kito, pateikiant juos linija išsirikiavusių krentančių domino kaladèlių metafora. Išskiriami NIt sekos 5 veiksniai: (1) socialinè aplinka ir paveldimumas (igimti ar socialinės aplinkos suformuoti nepageidaujami žmogaus asmenybès bruožai (pvz.: godumas, nerūpestingumas, neatsargumas, kt.), skatinantys žmogų nusižengti, suklysti), (2) žmogaus nusižengimas, klaida, (3) nesaugus veiksmas, aplinkybės (tiesiogine ịvykio priežastis), (4) ịvykis ir (5) nelaimingas atsitikimas (ivykio pasekmè) (žr. 5 pav.).

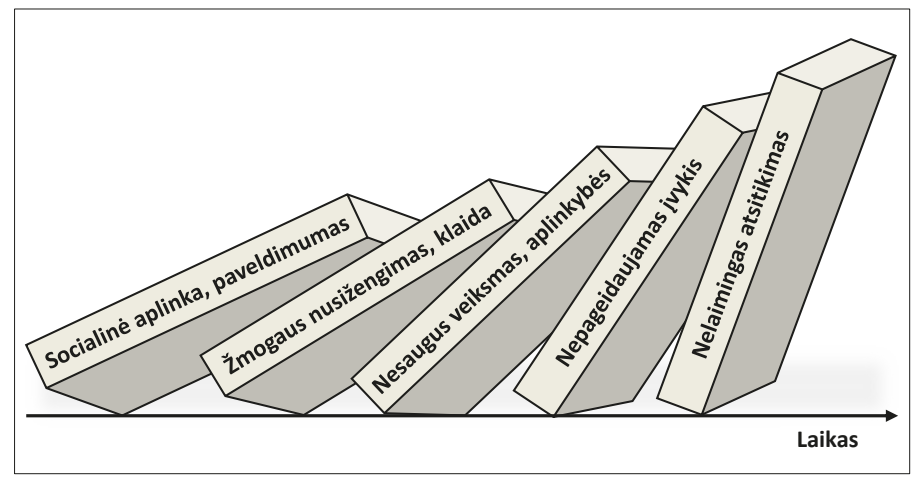

5 pav. Domino NI priežastingumo teorinis modelis (pagal H. W. Heinrich) ${ }^{34}$

Šaltinis: Heinrich, H. W., et al. 1980. Industrial Accident Prevention. New York: McGraw-Hill.

Trečias veiksnys „nesaugus veiksmas, aplinkybès“ laikomas pagrindiniu (svarbiausiu), siekiant išvengti NIt. Todẻl, pagal ši modelị, daugiausia dèmesio reikia skirti būtent šiam veiksniui, t. y. „išimti“ šią domino kaladèlę iš linijos ir kaladèlių griūtis bus sustabdyta ịvykis neįvyks, žala nebus padaryta (žr. „blogo obuolio teoriją“). Pagal ši modelị ryšiai tarp veiksnių yra nuoseklūs linijiniai, atspindèdami vienintelị NI priežasties-pasekmès kelią.

Pastebejus, kad moderniose sociotechninèse sistemose NIt sukelia ne vienas, bet kelių veiksnių kombinacija ir poveikis vienam iš veiksnių neužtikrina NI prevencijos ir sistemos saugos, iškilo poreikis naujam NI priežastingumo teoriniam pagrindui. Šią teorinę spragą užpildė J. Reason ${ }^{35}$, pasiūlydamas „Šveicariško sūrio“ modelį, pagrịstą sisteminių veiksnių priežastingumo teorija (žr. 6 pav.). „Epidemiologiniai ịvykio modeliai“ NI traktuoja kaip pasireiškimą i̇vairių tarpusavyje susijusių veiksnių, panaudodami „ligos“ metaforą, kuri pasireiškia susisumavus lètinėms (pvz.: stresas, nuovargis, žalingi ịpročiai, kt.) ir ūmioms (pvz.: ūmi infekcija) priežastims (pavojams), joms praejjus pro susilpnejusius organizmo sistemos apsaugos barjerus (pvz.: nusilpus imuninei sistemai, kt.) ir pasireiškus sveikatos sutrikimu (pasekme).

33 Heinrich, H. W., et al. Industrial Accident Prevention. New York: McGraw-Hill, 1980.

34 Heinrich, H. W., et al., supra note 33.

35 Reason, J. Managing the Risks of Organizational Accidents. Aldershot, Hants, Ashgate.1997. 


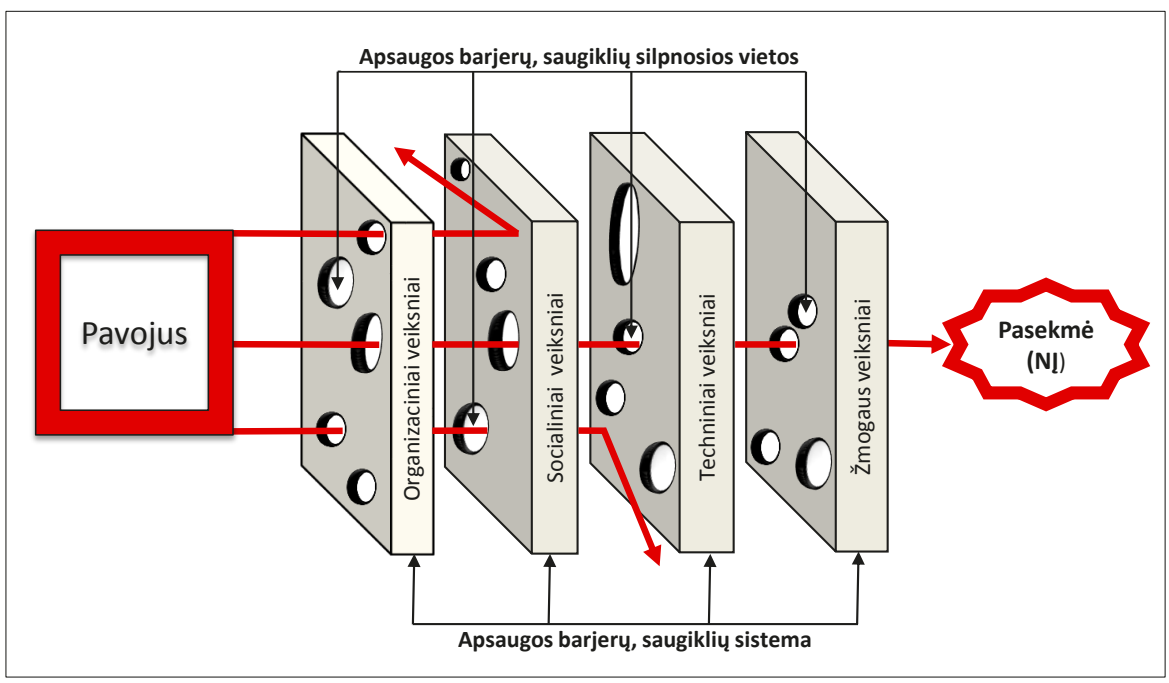

6 pav. Sisteminių veiksnių priežastingumo teorija (adaptuota pagal J. Reason „Šveicariško sūrio“ modelį) ${ }^{36}$

Šaltinis: Reason, J. Human error: models and management. BMJ. 2000, 320: 768-770.

Pagal J. Reason „Šveicariško sūrio“ modelį sistemos apsauginių komponentų silpnosioms vietoms išsirikiavus tiesia linija, nekliudomas pavojus pro jas praeina ir pasireiškia Nİ. Todèl būtina tobulinti struktūras ir procesus bei stiprinti apsauginius barjerus (inžinerinius, organizacinius, žmogiškuosius, kt.), sudèti saugiklius, kad sistemos defektai nesudarytų galimybès pavojui virsti NĮ. Aiškinantis ịvykusio NĮ priežastis svarbu ne tai, kas suklydo, bet kodèl nesuveikè sistemos apsaugos barjerai ir saugikliai bei neužkirto kelio žalingam veiksniui tapti Nİ (nepageidaujama pasekme). Tačiau epidemiologiniai ịvykio modeliai, vis dar išlaikantys nuoseklios multilinijine priežasčių-pasekmès seka pagrịsto Nİ priežastingumo požymius, atspindi statišką požiūrị i sistemą (organizaciją), tuo tarpu dinaminèse kompleksinèse sociotechninèse organizacijose apsaugos barjerai ir jų silpnosios vietos (skylès „Šveicariško sūrio" sluoksniuose) yra nuolatinès dinaminès būsenos.

Sisteminiai ịvykio modeliai, besiremiantys kompleksinès prisitaikančios sistemos koncepcija, pateikia naujovišką požiūrị i NI priežastingumą, apibūdindami ịvykị kaip naujai iškylantị (emergentinị) fenomeną, nulemtą kompleksinès žmonių, techninių, organizacinių ir aplinkos veiksnių tarpusavio priklausomybės ir sąveikos. SP organizacija laikoma ne statine, bet dinamine, nuolat besikeičiančia, prisitaikančia prie aplinkos pokyčiu, sistema. J. Rasmussen ${ }^{37}$ pasiūle Hierarchinị sociotechninị ịvykio priežastingumo modelį, ǐškirdamas du esminius sociotechninių sistemų rizikų valdymo komponentus: struktūinị ir dinaminị. Sociotechninès sistemos struktūra ịvairiuose lygmenyse ((L1) vyriausybès, (L2) reguliavimo funkcijas vykdančių organizacijų, asociacijų, sąjungų, (L3) organizacijos, (L4) vadybos, (L5) personalo ir (L6) darbo) patiria nuolatinị išorinès aplinkos spaudimą. Norint, kad sistema

36 Reason, J., supra note 16, p. 768-770.

37 Rasmussen, J. Risk Management in a Dynamic Society: A Modelling Problem. Safety Science. 1997, 27:183-212, 
funkcionuotų efektyviai, būtina užtikrinti dvikrypčius informacijos mainus: sprendimų (nurodymų) perdavimą (iš viršaus ł apačią) ir informacijos perdavimą atgaliniu ryšiu (iš apačios ị viršų). Saugos problemos atsiranda, kai organizacijoje neužtikrinama kontrolè dèl organizacijos struktūros lygmenų vertikalios integracijos pažeidimų, lygmenims patiriant skirtingus išorinės aplinkos poveikius. N!̨ ịvyksta dèl netobulų sprendimų priėmimo keliuose sistemos lygmenyse, o ne tik dèl priešakinèje linijoje dirbančių darbuotojų veiklos trūkumų. Modelio dinaminis aspektas grindžiamas tuo, kad organizacijos darbuotojų elgsena yra priklausoma nuo jų veiklos ir darbo aplinkos dinaminio konteksto. Dèl nuolat kintančios darbo aplinkos būtina apsibrežti saugios veiklos ribas (angl. boundaries of safe operations) bei identifikuoti dinamines jègas, dèl kurių poveikio kompleksinès sociotechninės sistemos juda link ar net peržengia nustatytas saugios veiklos ribas. Saugios veiklos ribos apibrežiamos trimis kraštinèmis: nepriimtino darbo krūvio, finansinių ir ekonominių apribojimų bei saugos reguliavimu ir procedūromis (̌̌r. 7 pav.).

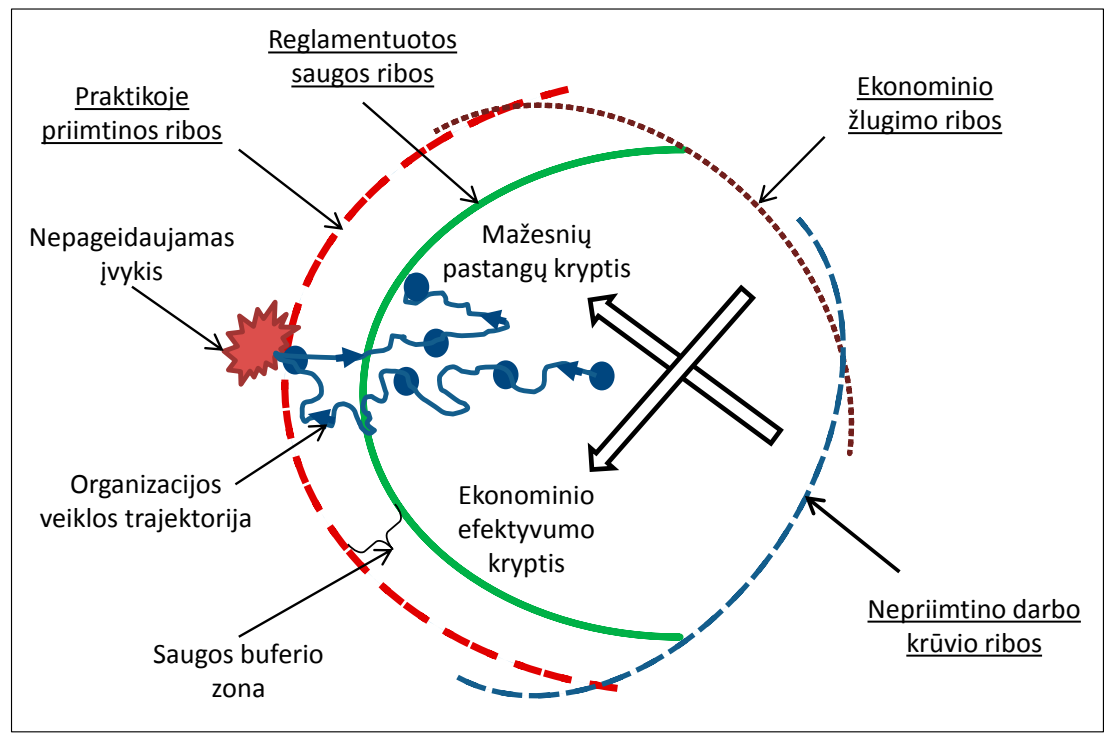

7 pav. Saugios veiklos ribos (adaptuota pagal J. Rasmussen) ${ }^{38}$

Šaltinis: Rasmussen, J. Risk Management in a Dynamic Society: A Modelling Problem. Safety Science. 1997, 27: 183-212.

Tačiau ekonominis spaudimas mažesniais ištekliais pasiekti daugiau rezultatų skatina darbuotojus priimti sprendimus ir judetti didesnio ekonominio efektyvumo kryptimi link reglamentuotos saugos ribų. Išaugę darbo krūviai motyvuoja darbuotojus priimti sprendimus, mažinančius protinị ar fizinị darbo krūvị, diegti inovacijas, judèti mažesnių pastangų kryptimi link saugos buferio zonos. Laikui bėgant, darbuotojų elgsena ir veikla pereina reglamentuotos saugos ribas ir juda link praktikoje priimtinos (išbandytos) elgsenos ir veiklos ribos. Ši darbuotojų elgsenos ir veiklos translokacija padidina rizikų ir NĮ tikimybę.

38 Rasmussen, J., supra note 37, p.183-212. 
Peržengus praktikoje priimtinas ribas, saugos buferinès zonos užribyje veikiant nepalankiems veiksniams bei susilpnẻjus kontrolei gali ịvykti NĮ. Todèl, kaip pažymi J. Rasmussen, būtina nustatyti aiškiai suprantamas saugios veiklos ribas, su jomis supažindinti darbuotojus bei užtikrinti jų elgsenos ir veiklos kontrolę, kad šios ribos nebūtų peržengtos.

Taikant kompleksinị sisteminị požiūrị NĮ priežastingumui nustatyti, svarbu ịvertinti SP organizacijos vidinès (mikro-, mezo-, makro-) ir išorinès (mega-, meta-) aplinkos dinamiką ir jos poveikị subsistemų lygmenims; anksčiau ịvairiuose sistemos struktūros lygmenyse priimtų sprendimų užprogramuotus, pasyviai budinčius sisteminius latentinius veiksnius, taip pat dinaminès aplinkos ịtaką darbuotojų elgsenai ir veiklai, skatinančią peržengti saugios veiklos ribas, bei užtikrinant reikiamų sistemos barjerų ir saugiklių, mažinančių riziką ir NI pasireiškimą, įdiegimą (žr. 8 pav.).

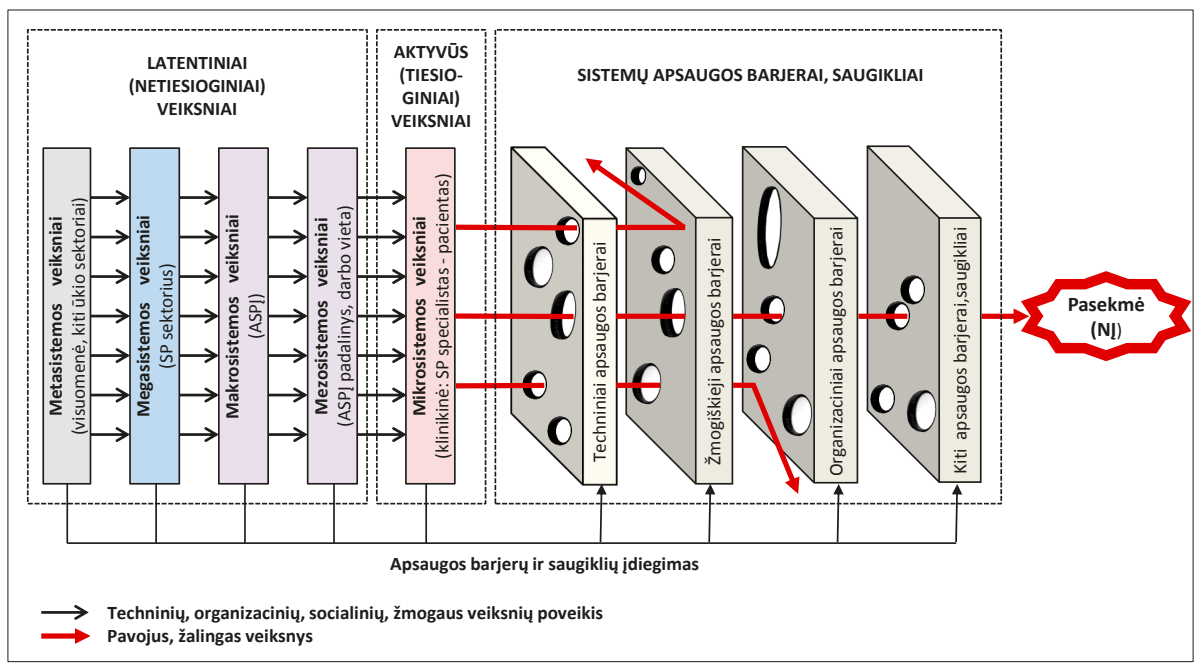

8 pav. Kompleksinis i̇vykių priežastingumo modelis (sudarytas autoriaus, pagal adaptuotus J. Reason ${ }^{39}$ ir J. Rasmussen ${ }^{40}$ ivvykių modelius)

Šaltiniai: Reason, J. Human error: models and management. BMJ. 2000, 320: 768-770;

Rasmussen, J. Risk Management in a Dynamic Society: A Modelling Problem. Safety Science.1997, 27: $183-212$.

\section{Sisteminis integralus požiūris ị PSRV SP organizacijose}

Sistemą galime apibrèžti kaip integruotą, glaudžiais tarpusavio ryšiais susijusị žmogiškųjų, intelektinių, kūrybinių, technologinių, informacinių, finansinių ir kitų išteklių tinklą ir jo veiklą, siekiant užsibrěžtų tikslų. SP sistema apibūdinama kaip kompleksiné, atvira, dinaminè, sparčiai besivystanti ir nuolat kintanti. C. Chantler pažymi, kad „seniau medicina buvo paprasta, neefektyvi ir santykinai saugi. Dabar ji yra sudetinga, efektyvi ir

\footnotetext{
39 Reason, J., supra note 16, p. 768-770.

40 Rasmussen, J., supra note 37, p. 183-212.
} 
potencialiai pavojinga ${ }^{\text {"41 }}$. Paradoksalu, bet technologinė pažanga nepadarè SP saugesnès pacientams, ASPİ darbuotojams. Išaugęs veiklos sudètingumas yra neatsiejamai susijęs su netikrumu ir rizika, kuri kelia problemų ir meta iššūkị ne tik mokslininkams ir profesionalams, ji kasdien verčia priimti sprendimus, kai reikia apsispręsti neturint pakankamos informacijos ${ }^{42}$.

Pacientų saugos ir rizikos valdymo SP sektoriuje sampratos evoliucijoje būtų galima išskirti šiuos etapus:

1. klaidų ir rizikos neigimo;

2. klaidų ir rizikos pripažinimo bei netoleravimo, „karo“ klaidoms ir kaltininkams paskelbimo;

3. rizikos suvokimo bei rizikos maksimalaus vengimo:

3.1. kuriant saugią (be rizikos) aplinką;

3.2. puoselejjant saugos kultūrą SP sektoriuje ir SP organizacijose;

3.3. diegiant NI raportavimo (registravimo) ir mokymosi iš nesèkmių sistemas nacionaliniu (šalies), lokaliu (ASPț) lygiais;

4. rizikos minimizavimo iki priimtino lygmens, stiprinant saugos barjerus ir diegiant PSRVS.

Sistemos saugą galima apibrěžti kaip sistemos charakteristikas, kurių dèka sistema išvengia netekčių bei nuostolių, susijusių su žmonių sveikata ar gyvybe, materialinėmis bei nematerialinėmis vertybėmis ar aplinka. Nèra tokios sistemos, kuri būtų visiškai saugi, nèra nė vienos saugos ir rizikos valdymo sistemos, kuri visiškai užtikrintų saugą. SP organizacijose rizikos turi būti valdomos diegiant PSRVS, minimizuojant rizikas iki minimalaus priimtino lygmens. Šiam tikslui pasiekti siūlomas sisteminis integralus požiūris ị PSRV SP organizacijose, kuris turi būti orientuotas tiek ì praeitị - tiriant Nİ ir mokantis iš buvusių nesèkmių; tiek ì dabarti - efektyviai valdant NIt, minimizuojant jų poveikị bei sukeliamą žalą čia ir dabar; tiek $\mathfrak{i}$ ateit - identifikuojant potencialią PSI riziką ir imantis priemonių sumažinant jų pasireiškimo riziką iki mažiausio priimtino lygmens.

Apibendrintus mokslinès literatūros šaltiniuose paminètus SP sektoriuje plačiau paplitusius PSRV modelius bei technikas galima suskirstyti į reaktyvius, interaktyvius ir proaktyvius:

1. Reaktyvus, retrospektyvinis (angl. reactive, retrospective) - apima $\mathrm{NI}$ ištyrimo ir analizès metodus, siekiant nustatyti jų tikrąsias (gilumines) priežastis bei jas lemiančius veiksnius ir imtis veiksmų, kad šie nepasikartotų ateityje. Taikomi metodai: klinikinis auditas (angl. Clinical Audit), pagrindinès priežasties analizė (angl. Root Cause Analysis), reikšmingų ịvykių auditas (angl. Significant Event Audit), reikšmingų ịvykių analizė (angl. Significant Event Analysis), sistemų analizė (angl. Systems Analysis); NI registravimo ir mokymosi sistema (angl. Adverse Events Reporting and Learning System), kt.

2. Interaktyvus (angl. interactive) - apima ką tik įvykusio ar bevykstančio NĮ bei jo padarinių valdymą, minimizuojant jo pasireiškimo žalą (neigiamas pasekmes) pacientams, lankytojams, ASPİ darbuotojams. Naudojamos NI pobūdị atitinkančios, jo poveikị mažinančios priemonès.

3. Proaktyvus (angl. proactive) - apima PSI atsiradimo ir pasireiškimo prognostinius bei prevencinius veiksmus, siekiant, kad jie nepasireikštų ateityje:

3.1. Retrospektyvinis proaktyvus (angl. retrospective - proactive), dar vadinamas reaktyvia prevencija (angl. reactive prevention), - igyvendinami prevenciniai veiksmai

${ }^{41}$ Chantler, C. The role and education of doctors in the delivery of health care. Lancet. 1999, 353: 1181.

${ }^{42}$ Janušonis, V. Rizikos valdymas sveikatos priežiūros organizacijose. Klaipèda: S. Jokužio leidyklaspaustuvè, 2005. 
pagal turimą savo ar kitų praeities patirtį, besimokant iš galejusių îvykti, bet ne¡̇vykusių (angl. near misses, close calls), savanoriškai pranešamų PSİ, siekiant užkirsti kelią jau ịvykusių PSI pasikartojimui organizacijoje identiškose ar panašiose situacijose. Taikomi metodai: ịvykių medžio analizè (angl. Event Tree Analysis), savanoriška PSI registravimo ir mokymosi sistema (angl. Voluntary Patient Safety Events Reporting and Learning System), nesèkmès modelio ir poveikio analizè (angl. Failure Mode and Effects Analysis), nesèkmès modelio ir poveikio analize sveikatos priežiūroje (angl. Failure Mode and Effects Analysis in Healthcare), saugos auditas (angl. Safety Audit), rizikos veiksnių analizè ir svarbiausi kontrolès taškai (angl. Hazard Analysis and Critical Control Points), kt.

3.2. Perspektyvinis proaktyvus, prognostinis (angl. predictive), dar vadinamas proaktyvia prevencija (angl. proactive prevention), - igyvendinami prevenciniai veiksmai prognozuojant (nuspèjant, modeliuojant, kt.) veiksnius, ateityje galinčius paskatinti potencialių PSİ atsiradimą, identifikuojant potencialius veiksnius, jų tarpusavio sąveikos ir pasireiškimo mechanizmus, sustiprinant esamus bei ịvedant naujus PSI pasireiškimą ribojančius barjerus, saugiklius. Taikomi metodai: rizikų tikimybès ivertinimas (angl. Probabilistic Risk Assessment), kt.

SP organizacijos dažniausiai igyvendina retrospektyvinius PSRV metodus bei technikas analizuodamos įvykusius esminę žalą padariusius NĮ. Tyrinėdamas NĮ pasireiškimo priežastis ir mechanizmus, C. A. Vincent ${ }^{43}$ pažymi, kad NĮ yra tarsi „langas ị sistemą“, pro kurị išvystame daugelị veiksnių, turèjusių ịtakos ịvykio atsiradimui, bei sąlygas, prisidẻjusias prie nepageidaujamos pasekmés pasireiškimo. Vien tik reaktyvus požiūris ị PSRV nèra pakankamas minimizuojant riziką pacientams $\mathrm{s}^{44}$, būtinas proaktyvus rizikos ir klaidų numatymas ${ }^{45}$, tikslu nustatyti, ìvertinti, eliminuoti ar sumažinti klaidụ pasireiškimo riziką ${ }^{46}$. Moksliniai tyrimai PS srityje atskleide, kad igyvendinimas tik reaktyvių ar tik proaktyvių PSRV metodų nesuteikia išsamaus vaizdo apie PSİ rizikas ir jų prigimtị, nes abu šie požiūriai, kuriais grindžiami metodai, turi savų trūkumų ${ }^{47},{ }^{48}$. „Auksinio standarto" PSRV srityje kol kas nèra sukurta, todèl šiuo metu kompleksinis sisteminis integralus požiūris ị PSRV, ịvertinantis SP organizacijų sociotechninị kompleksiškumą ir dinamiškumą, sujungiantis reaktyvius, interaktyvius ir proaktyvius PSRV modelius bei technikas, suteikiantis galimybę identifikuoti ir šalinti esamas sistemos spragas, efektyviai valdyti įvykusius ar vykstančius Nİ bei įvertinti (nuspèti) PS ateities problemas, identifikuojant potencialias rizikas, yra rekomenduotinas SP organizacijoms.

Šiame straipsnyje apžvelgus tradicinio ir modernaus požiūrių ị PS teorinius aspektus, pateiktos kompleksinio sisteminio integralaus požiūrio ị PSRV mokslinès įžvalgos, svarbios konstruojant, diegiant bei tobulinant PSRV sistemas, modelius, technikas ar priemones, siekiant užtikrinti optimalų PS lygị kompleksinèse sociotechninèse SP organizacijose.

43 Vincent, C. A. Analysis of clinical incidents: a window on the system not a search for root causes. Qual Saf Health Care.2004,13: 242-243.

44 Battles, J. B.; Lilford, R. J. Organizing patient safety research to identify risks and hazards. Quality and Safety in Health Care. 2003, 12 (Suppl.2): ii2-ii7.

45 Hollnager, E. Risk + barriers = safety? Safety Science. 46: 221-229.

46 Battles, J. B., et al. Sensemaking of patient safety risks and hazards. Health Services Research. 2006, 41: 1555-1575.

47 Bonnabry, P., et al. Use of prospective risk analysis method to improve the safety of the cancer chemotherapy process. International Journal for Quality in Health Care. 2006, 18: 9-16.

48 Hogan, H., et al. What can we learn about patient safety from information sources within an acute hospital: A step on the ladder of integrated risk management? Quality and Safety in Health Care. 2008, 17: 209-215. 


\section{Išvados}

1. Sveikatos priežiūros organizacijos priskiriamos kompleksinėms (sudètinèms) atviroms dinaminėms sociotechninėms sistemoms. Tokių sistemų funkcionavimas nuolat kintančioje aplinkoje suponuoja kompleksinių (nelinijinių) rizikų radimąsi. Kompleksinèse sistemose valdant riziką izoliuotai, veikiant vieną sistemos grandị ar elementą, poveikis gali turèti ịtakos kitos rizikos kitoje vietoje, kitu laiku atsiradimui. Sauga sveikatos priežiūroje yra ne statinio, bet dinaminio pobūdžio, todèl rizikų genezès, transformacijos ir poveikio kompleksiškumo supratimas yra labai svarbus renkantis ir diegiant pacientų saugos ir rizikos valdymo sistemas, modelius, technikas bei priemones sveikatos priežiūros organizacijose.

2. Kompleksinis sisteminis integralus požiūris ì pacientų saugą ir rizikos valdymą turètų ịvertinti sveikatos priežiūros organizacijos vidinès (mikro-, mezo-, makro-) ir išorinès (mega-, meta-) aplinkos bei jos pokyčių svarbą pacientų saugai; būti orientuotas tiek ì praeitị (reaktyvus), užtikrinant mokymąsi iš NIt, tiek ị dabartị (interaktyvus), minimizuojant Nİ neigiamą poveikį, tiek ị ateitị (proaktyvus), prognozuojant, identifikuojant bei užkertant kelią potencialioms rizikoms pasireikšti NIt.

3. Kompleksinio sisteminio integralaus požiūrio ì pacientų saugą ir rizikos valdymą igyvendinimas suteiktų galimybę sveikatos priežiūros organizacijoms nuspèti bei efektyviau valdyti rizikas, užtikrinant optimalų pacientų saugos lygị.

\section{Literatūra}

1. An Organization with a Memory. Report of an Expert Group on Learning from Adverse Events in the NHS Chaired by the Chief Medical Officer [interaktyvus]. London.The Stationary Office. 2000 [žiūrèta 2013-12-11]. <http://www.aagbi.org/sites/default/files/ An\%20organisation\%20with\%20a\%20memory.pdf $>$.

2. Analizė apie galimybę sukurti nepageidaujamų ịvykių ir gydymo klaidų registracijos sistemą. Galutinè sutarties vykdymo ataskaita [interaktyvus]. Vilnius. 2013 [žiūrèta 2013-12-05]. <http://www.sam.lt/go.php/lit/>.

3. Baker, G. R.; Norton, P. G., Flintolf, V., et al. The Canadian Adverse events Study: the incidence of adverse events among hospital patients in Canada. Canadian Medical Association Journal. 2004, 179(11): 1678-1686.

4. Bar-Yam, S., et al. A Complex Systems Science Approach to Healthcare Costs and Quality. New England Complex Systems Institute [interaktyvus]. USA, 2012 [žiūrèta 2013-12-28]. $<$ http://www.necsi.edu/research/management/health $>$.

5. Battles, J. B., et al. Sense making of patient safety risks and hazards. Health Services Research. 2006, 41: 1555-1575.

6. Battles, J. B.; Lilford, R. J. Organizing patient safety research to identify risks and hazards. Quality and Safety in Health Care. 2003, 12 (Suppl.2): ii2-ii7.

7. Bonnabry, P., et al. Use of prospective risk analysis method to improve the safety of the cancer chemotherapy process. International Journal for Quality in Health Care. 2006, 18: 9-16.

8. Building a safer NHS for patients. Implementing an Organization with a memory. [interaktyvus]. 2002 [žiūrèta 2013-12-11]. <http://158.132.155.107/posh97/private/GSP/ NHS.pdf $>$.

9. Canadian Incident Analysis Framework. 2012. Canadian Patient Safety Institute [interaktyvus]. 2012 [žiūrèta 2013-12-21]. <http://www.patientsafetyinstitute.ca>. 
10. Chantler, C. The role and education of doctors in the delivery of health care, Lancet. 1999, 353: 1181.

11. Davis, M. C., et al. Advancing socio-technical systems thinking: A call for bravery. Applied Ergonomics. 2014, 45 (2): 171-180.

12. Davis, P., et al. Adverse events in New Zealand public hospitals: occurrence and impact. New Zealand Medical Journal. 2002,115 (1167): U271.

13. ES Tarybos $2009 \mathrm{~m}$. birželio $9 \mathrm{~d}$. Rekomendacija dèl pacientų saugos ir su sveikatos priežiūra susijusių infekcijų prevencijos ir kontrolès 2009/C 151/01 [interaktyvus]. 2009. [žiūrèta 2013-12-09].<http://ec.europa.eu/health/patient_safety/docs/council_2009_lt.pdf>.

14. Governments and patient safety in Australia, the United Kingdom and the United States. A review of policies, institutional and funding frameworks, and current initiatives. Report prepared for the Advisory Committee on Health Services by Working group on Quality of Health Care Services. 2002.

15. Health Grades Quality study. Second Annual. Patient Safety in American Hospital Report [interaktyvus]. 2005 [žiūrèta 2013-12-11]. <http://hg-article-center. s3-website-us-east-1.amazonaws.com/a6/43/b94f277e492d9a416af1d51b487d/ PatientSafetyInAmericanHospitalsReport2005.pdf $>$.

16. Heinrich, H. W., et al. Industrial Accident Prevention. New York: McGraw-Hill, 1980.

17. Hobbs, A., et al. Three principles of human-system integration. Proceedings of the 8th Australian Aviation Psychology Symposium [interaktyvus]. Sydney, Australia, 2008 [žiūrèta 2013-12-28]. <http://humansystems.arc.nasa.gov/publications/3Principles_HSI.pdf>.

18. Hogan, H., et al. What can we learn about patient safety from information sources within an acute hospital: A step on the ladder of integrated risk management? Quality and Safety in Health Care. 2008,17: 209-215.

19. Hollnager, E. Risk + barriers = safety? Safety Science. $46: 221-229$.

20. Institute of Medicine. Committee on Quality of Health Care in America. To Err is Human: Building a Safer Health System. Washington, DC: National academy Press, [interaktyvus]. 2000 [žiūrèta 2013-12-28]. <https://download.nap.edu/login.php?record_ id=9728\&page $=\% 2$ Fdownload.php\%3Frecord_id\%3D9728 $>$.

21. Janušonis, V. Rizikos valdymas sveikatos priežiūros organizacijose. Klaipėda: S. Jokužio leidykla-spaustuve, 2005.

22. Johnson, C. W.; Holloway, C. M. A Longitudinal Analysis of the Causal Factors in Major Maritime Accidents in the USA and Canada (1996-2006). Proceedings of the 15th SafetyCritical Systems Symposium. Bristol, UK. The Safety of Systems. 2007, 85-94.

23. Lee, R. C.; Donaldson, C.; Cook, L. S. The need for evolution in healthcare decision modeling. Medical Care. 2003, 41(9): 1024-1033.

24. Nelson, E. C., et al. Clinical microsystems, part 1. The building blocks of health systems. Joint Commission Journal on Quality and Patient Safety. 2008, 34(7): 367-378.

25. Nepageidaujami ịvykiai ir jų priežastys sveikatos priežiūros specialistų ir pacientų požiūriu. Higienos institutas, 2008.

26. Patient safety: towards sustainable improvement. Fourth report to the Australian Health Ministers' Conference. Australian council for safety and quality in health care. Commonwealth of Australia 2003.

27. Plsek, P. E.; Greenhalgh, T. Complexity science: The challenge of complexity in health care. BMJ. 2001, 323: 62--628.

28. Plsek, P. E.; Wilson, T. Coplexity science. Complexity, leadership, and management in healthcare organizations. BMJ. 2001, 323:746-749. 
29. Qureshi, Z. H. A Review of Accident Modeling Approaches for Complex Critical Sociotechnical Systems. Technical Report. 2008.

30. Rasmussen, J. Risk Management in a Dynamic Society: A Modeling Problem. Safety Science. 1997, 27: 183-212.

31. Reason, J. Human error: models and management. BMJ. 2000, 320: 768-770.

32. Reason, J. Managing the Risks of Organizational Accidents. Aldershot, Hants, Ashgate. 1997.

33. Sharpe, V. A.; Faden, A. I. Medical Harm. Historical, Conceptual and Ethical Dimensions of Iatrogenic Illness. Cambridge University Press. Cambridge, 1998.

34. Smits, M., et al. Exploring the causes of adverse events in hospitals and potential prevention strategies. Quality and Safety in Health Care. 2010,19(5): e5.

35. Standing Committee of the Hospitals of the EU. The quality of health care/hospital activities: Report by the Working Party on quality care in hospitals of the subcommittee on coordination. 2000.

36. Stolzer, A. J.; Halford, C. D.; Goglia, J. J. Safety Management Systems in Aviation. Ashgate Studies in Human Factors for Flight Operations. Burlington: Ashgate Publishing Company, 2013.

37. Takayanagi, K.; Hagihara, Y. Revised sunflower - SHELL model - an analysis tool to ensure averse events' factor analysis and followed by patient safety strategy. Jpn Hosp. Jan 2007, (25): 11-18.

38. Thomas, E. J., et al. Incidence and types of adverse events and negligent care in Utah and Colorado. Med Care. 2000, 38:261-271.

39. Vincent, C. A. Analysis of clinical incidents: a window on the system not a search for root causes. Qual Saf Health Care. 2004, 13: 242-243.

40. Wheatley, M. Finding Our Way: Leadership for an Uncertain Time. Berrett-Koehler Publishers. San Francisco, CA. 2005.

\title{
The Importance of the Complex Approach towards Patient Safety and Risk Management in Healthcare Organizations
}

\author{
Laimutis Paškevičius
}

Mykolas Romeris University, Lithuania

\section{Summary}

Patients have a right to safe and high-quality health care. However, research in the field of patient safety shows that adverse events in healthcare have significant moral, social and financial costs for societies, healthcare sectors and institutions. Global changes are stimulating healthcare sector and its organizations to pay more attention to the safety and quality of health care services, introduce patient safety and risk management systems.

However, due to the lack of complex and systematic approach to the patient safety and risk management, patient safety interventions at the national (country) and local (institutional) levels are often inefficient.

The aim of the article is to highlight the importance of the complex approach toward patient safety and risk management in healthcare institutions. 
Therefore, in the article the complex approach towards patient safety and risk management is presented and its importance is stressed in planning and implementing patient safety and risk management systems and instruments for health care organizations.

Keywords: patient safety, risk management, adverse event, complex approach, sociotechnical system.

Laimutis Paškevičius, Mykolas Romeris University, Faculty of Policy and Management, Institute of Political Sciences, Doctoral student. Research interests: healthcare management, healthcare quality, patient safety, risk management, management, human resources management, strategic management, operational management.

Laimutis Paškevičius, Mykolo Romerio universiteto Politikos ir vadybos fakulteto Politikos mokslų instituto doktorantas. Mokslinių tyrimų kryptys: sveikatos priežiūros vadyba, sveikatos priežiūros kokybè, pacientų sauga, rizikos valdymas, vadyba, žmonių išteklių vadyba, strateginis valdymas, operatyvusis vadovavimas. 